\title{
Property and the Roberts Court
}

\author{
John G. Sprankling *
}

\section{INTRODUCTION}

How do property owners fare before the Roberts Court? Quite well. Owners prevail in $86 \%$ of civil property-related disputes with government entities. ${ }^{1}$ But this statistic does not tell the whole story. This Article demonstrates that under the leadership of Chief Justice Roberts the Court has expanded the constitutional and statutory protections afforded to owners to a greater extent than any prior Court. It analyzes the key trends in the Court's jurisprudence that will shape its decisions on property issues in future decades.

Almost 100 years ago, Justice Holmes remarked that government regulation of property which went "too far" would be unconstitutional; yet the precise line between permissible and impermissible action has never been drawn. ${ }^{2}$ The issue has generated debate through much of American history, particularly in recent decades as the influence of conservative ideology on the Supreme Court has expanded. The Burger and Rehnquist Courts were broadly viewed as more sympathetic to private property than the Warren Court had been. However, the most controversial anti-owner decision of the modern era, Kelo v. City of New London, ${ }^{3}$ was decided in the final year of the Rehnquist Court. In Kelo, the Court held that the city was empowered to condemn owner-occupied homes and transfer them to private developers as part of an economic redevelopment project ${ }^{4}-\mathrm{a}$ ruling that ignited a firestorm of protest across the nation.

In his confirmation hearings to serve as Chief Justice, John Roberts pledged to act as an "umpire" on the Court, a person with "no agenda"

\footnotetext{
* Distinguished Professor of Law, University of the Pacific, McGeorge School of Law. I thank McGeorge students Hannah Fuetsch and Alexandra Smith for their excellent research assistance.

1. See infra Appendix.

2. Pa. Coal Co. v. Mahon, 260 U.S. 393, 415 (1922).

3. 545 U.S. 469 (2005).

4. Id. at $489-90$.
} 
who would merely "call balls and strikes, and not... pitch or bat.", These statements suggested that his approach to controversial issues such as the scope of property rights would be relatively neutral-and they also implied that he hoped to shift the entire Court in this direction. But in fact, the Court's decisions in property-related disputes have been far from evenhanded.

The most striking feature of the Roberts Court property jurisprudence is its strong protection of property owners against government conduct-in contexts ranging from wetlands regulation to gun ownership to zoning. As discussed in Part II of the Article, statistical analysis reveals that in civil property-related disputes between property owners and government entities, owners almost always win in the Roberts Court. Conversely, owners usually lose in property-related disputes involving criminal law.

Part III analyzes four substantive themes that help to explain how the Roberts Court has reshaped the Court's historic approach to property law, focusing on civil cases that involve constitutional issues. ${ }^{6}$ First, the Court has increasingly "propertized" the Constitution by interpreting the Second and Fourth Amendments through a property lens and by enlarging the scope of the Fifth Amendment's Takings Clause. Second, the Court's greater dedication to safeguarding homes has contributed toward its pro-owner orientation. Third, the Court's decisions have apparently been influenced by heightened distrust of government officials to adequately respect property rights. Finally, the Court has begun to redefine the scope of what constitutes "property" in a manner that increasingly expands the rights of owners.

Part IV explores how the Court's property jurisprudence will evolve in the wake of Justice Scalia's death. When the Roberts Court era began, Scalia's influence on property doctrine was so powerful that it would have been impossible to foresee how the Court might approach the subject in his absence. But the four core themes developed in the first

5. Confirmation Hearing on the Nomination of John G. Roberts, Jr. to Be Chief Justice of the United States: Hearing Before the S. Comm. on the Judiciary, 109th Cong. 56 (2005) (statement of John G. Roberts, Jr., to be Chief Justice of the United States).

6. Although it is conventional to categorize eras of Supreme Court jurisprudence according to the identity of the Chief Justice, the composition of the Court inevitably changes. To date, three new Justices have joined the Court during Chief Justice Roberts' tenure: Justice Alito replaced Justice O'Connor in 2006; Justice Sotomayor replaced Justice Souter in 2009; and Justice Kagan replaced Justice Stevens in 2010. In practical terms, part of the Court's heightened focus on protecting property owners may stem from Justice Alito, who is somewhat more likely than Justice O'Connor to adopt pro-owner positions. Justice Scalia's replacement on the Court will undoubtedly also affect the evolution of its property jurisprudence. 
decade of the Roberts Court-spurred in part by its new membership-will form the foundation for its property jurisprudence in coming years, allowing us to draw preliminary conclusions about how the Court will address property issues in the future.

\section{OWNER V. GOVERNMENT: WHO WINS IN THE ROBERTS COURT?}

\section{A. Civil Cases}

In McBurney v. Young, the Roberts Court unanimously proclaimed that the right to "take, hold and dispose of property, either real or personal,' has long been seen as one of the privileges of citizenship"-citing a case decided almost 200 years ago. ${ }^{7}$ Consistent with this pro-owner orientation, the Court has generally shielded owners against government action in civil cases, despite ongoing debate about the appropriate scope of property rights. ${ }^{8}$

Discourse on protecting private property rights from government encroachment centers on civil cases. Yet civil disputes between owners and government entities that reach the Supreme Court are relatively rare. Property issues surface occasionally in constitutional law, mainly in cases involving the Takings Clause of the Fifth Amendment or the Due Process Clause of the Fifth and Fourteenth Amendments. But disputes arising under the First, Second, Third, and Fourth Amendments may also affect property rights; and federal statutes ranging from the Clean Water Act to the Religious Freedom Restoration Act to the Fair Housing Act may have a similar impact. This Article accordingly takes a broad view of what constitutes a "property-related dispute" between an owner and a government entity, including disputes involving rules that go well beyond core property law doctrines, as discussed in the Appendix.

In general, a "property-related dispute" as used in this Article connotes a lawsuit between an owner and a government entity where legislation, administrative decisions, or other official actions allegedly infringe private property rights - the contents of the metaphorical bundle of sticks. The Roberts Court has now generated enough decisions in property-related disputes to permit a preliminary study of its overall approach.

7. 133 S. Ct. 1709, 1716 (2013) (quoting Corfield v. Coryell, 6 F. Cas. 546, 552 (C.C.E.D. Pa. 1823)).

8. As Justice Stevens observed in Doe v. Reed, 561 U.S. 186, $218-19$ (2010) (Stevens, J., concurring), "[d]ebates about... regulation of private property can become just as heated as debates about domestic partnerships." 
In order to determine how property owners fared, I examined the twenty-nine decisions issued by the Roberts Court prior to Justice Scalia's death that involved a civil property-related dispute in which an owner was either a petitioner or respondent and the opposing party was a government entity. ${ }^{9}$ The outcome of this study was a remarkable finding: the owner won in $86 \%(25 / 29)$ of these decisions. It should be stressed that this result is based on both a relatively small number of decisions and a generous definition of what may be classified as a "property-related dispute." Accordingly, the finding is best viewed as a tentative indication rather than as a statistically significant conclusion. Yet, at a minimum, it suggests that far from serving as a neutral umpire, the Roberts Court generally favors owners over government entities.

\section{B. Criminal Cases}

Although property-rights scholarship focuses on civil cases, property rights are obviously at stake in a variety of lawsuits connected to criminal law. Most commonly, an owner seeks to exclude evidence against her in a criminal trial based on an alleged Fourth Amendment violation or argues that a statute concerning a property-related crime does not apply to her situation. An owner might sue for damages for an alleged wrongful search by law enforcement officers under Bivens v. Six Unknown Named Agents of Federal Bureau of Narcotics. ${ }^{10}$ Or an inmate might complain that prison officials violated his rights to acquire or possess property. The outcome in property-related disputes in the criminal law setting is sharply different from the result in civil cases.

During the study period, the Roberts Court decided thirty-two criminal property-related disputes in which the parties were a property owner (normally one accused or convicted of a crime) and a government entity. ${ }^{11}$ In contrast with the Court's rulings in the civil context, the owner prevailed in only $38 \%(12 / 32)$ of these cases.

Despite the general pro-owner orientation of the Roberts Court, this result is not surprising because these categories of cases trigger policy concerns quite different from those in civil cases. The retribution and deterrence goals of criminal law weigh heavily against efforts to exclude evidence based on an allegedly unconstitutional search, especially because police officers must be afforded a considerable amount of

. See the Appendix for a list of these decisions.

10. 403 U.S. 388 (1971).

11. See the Appendix for a list of these decisions. 
deference for quick decisions made in the course of criminal investigations. In Bivens cases, officers are entitled to qualified immunity from liability unless their conduct was "plainly incompetent"12 - a difficult standard for an owner to meet. And in cases involving inmate property, courts typically accord officials wide discretion given the challenges of prison operation.

But statistics-standing alone-provide only limited assistance in understanding the Roberts Court's orientation toward property issues in criminal proceedings. Although the Court substantially enlarged the scope of Fourth Amendment protection afforded to property owners, ${ }^{13}$ this development is masked by the overall decision count.

\section{CORE THEMES IN ROBERTS COURT PROPERTY JURISPRUDENCE}

\section{A. From Umpire to Guardian}

The Roberts Court has emerged as a staunch guardian of property rights, despite John Roberts' statement during his confirmation hearings that he would view his role as an umpire. It is hardly shocking that a Court influenced by conservative Justices would tend to protect private property. Nor should an observer be startled if the decision of a Justice in a specific case might appear to differ from general comments he or she made during confirmation hearings.

Yet two aspects of the Roberts Court approach to property are somewhat surprising: (1) the extent to which it favors owners over government in civil property-related disputes, as discussed in Part II above; and (2) the specific mechanisms that the Court has utilized in its property jurisprudence, as discussed below.

Four key themes dominate the Court's property jurisprudence and thus help to explain its focus on protecting owners in civil propertyrelated disputes. First, more than its predecessors, the Roberts Court has engaged in "propertizing" the Constitution: it is reinterpreting key constitutional provisions through a property lens in a manner than tends to safeguard owners. ${ }^{14}$ In a similar vein, it exhibits significantly greater

12. Ashcroft v. al-Kidd, 563 U.S. 731, 743 (2011) (quoting Malley v. Briggs, 475 U.S. 335, 341 (1986)).

13. See infra Section III.B.3.

14. The same tendency is evident in non-constitutional decisions, particularly those that involve statutory construction. See, e.g., Tex. Dep't of Hous. \& Cmty. Affairs v. Inclusive Cmtys. Project, Inc., 135 S. Ct. 2507 (2015) (Fair Housing Act); Sackett v. EPA, 132 S. Ct. 1367 (2012) (Clean Water Act); United States v. Atl. Research Corp., 551 U.S. 128 (2007) (Comprehensive 
reverence for the home than its predecessors, increasingly shielding the home from government action. A third theme seems to be distrust of government officials to respect property rights, which is deployed to justify enhanced protection for owners. Finally, and more broadly, the Court is shifting the boundaries of what constitutes "property" in a manner that tends to favor owners.

\section{B. "Propertizing" the Constitution}

\section{Constitutional Property}

Scholars have viewed the Constitution as creating two distinct forms of protection for private property, one general and one specific. The Due Process Clause ${ }^{15}$ and the Takings Clause ${ }^{16}$ of the Fifth Amendment protect "property" in general against certain actions of the federal government, and the Fourteenth Amendment extends the scope of these clauses to encompass actions by state and local governments. ${ }^{17}$ "Property," as used in this context, is defined by a source outside of the Constitution itself, most commonly state law. In contrast, the Third and Fourth Amendments extend constitutional protection to specific objects of property rights. The Third Amendment protects the "house," 18 while the Fourth Amendment applies to "houses, papers, and effects." 19 Thus, the Third and Fourth Amendments may each be viewed as creating a sort of "super-property right" whose interpretation is governed by federal law. Due to their constitutional genesis, these super-property rights necessarily trump inconsistent state law.

The dominant theme in the property jurisprudence of the Roberts Court is what might be the "propertization" of the Constitution, that is,

Environmental Response, Compensation, and Liability Act); Rapanos v. United States, 547 U.S. 715 (2006) (Clean Water Act); Ark. Dep't of Health \& Human Servs. v. Ahlborn, 547 U.S. 268 (2006) (Medicaid statute). See also the Appendix for other cited Roberts Court decisions.

15. The Due Process Clause provides: "No person shall... be deprived of ... property, without due process of law ...." U.S. CONST. amend. V.

16. The Takings Clause provides: "[N]or shall private property be taken for public use, without just compensation." U.S. CONST. amend. V.

17. The term "property" also occurs in Article IV of the Constitution, which authorizes Congress to dispose of and otherwise deal with "the Territory or other Property belonging to the United States." U.S. CONST. art. IV, § 3, cl. 2.

18. The Third Amendment provides: "No Soldier shall, in time of peace be quartered in any house, without the consent of the Owner, nor in time of war, but in a manner to be prescribed by law." U.S. CONST. amend. III.

19. The Fourth Amendment provides: "The right of the people to be secure in their persons, houses, papers, and effects, against unreasonable searches and seizures, shall not be violated...." U.S. CONST. amend. IV. 
expanding property themes in constitutional doctrine. This transition is reflected in the Court's revolutionary decisions reinterpreting the protection accorded to specific forms of property in the Second and Fourth Amendments, and in its major opinions enlarging the scope of the Takings Clause to protect property in general.

The Roberts Court has reshaped Second Amendment jurisprudence to the point where the amendment comes close to creating a new specific constitutional property right-the right to possess a handgun. It has transformed the standard used to determine whether a search has occurred under the Fourth Amendment by adopting a property-based approach, overturning almost fifty years of case law. Finally, it has broadened the reach of the Takings Clause, thus enhancing the ability of property owners to seek compensation for government action. ${ }^{20}$

To a degree, this trend continues an approach established during the Burger and Rehnquist Court eras. But the Roberts Court has proven to be more aggressive in propertizing the Constitution than past courts have been-despite its repeated endorsement of the maxim that the Court should be particularly reluctant to overturn prior decisions concerning property rights. $^{21}$

The key Roberts Court opinions in the propertization process tend to share three characteristics. First, they were written by Justices associated with the conservative wing of the Court-Chief Justice Roberts and Justices Scalia and Alito. Second, these decisions generally seek to establish bright-line rules, as opposed to case-by-case standards. Finally, they often reflect an originalist orientation, grounded in historical analysis of property doctrines as they existed when the Bill of Rights was ratified.

\section{Second Amendment}

The Second Amendment attracted little judicial attention for most of

\footnotetext{
20. In contrast, the Roberts Court has done less to expand the boundaries of the Due Process Clause in the property context. In Jones v. Flowers, 547 U.S. 220 (2006), the Court held that merely mailing notices of a tax sale to the owner did not comply with the Clause where the notices were returned as undeliverable. See also Philip Morris USA v. Williams, 549 U.S. 346, 349 (2007) (jury award of punitive damages based in part on desire to punish persons not before the trial court violated the Due Process Clause as a "taking of 'property' ... without due process").

21. See, e.g., Citizens United v. Fed. Election Comm'n, 558 U.S. 310, 365 (2010) (observing that in applying stare decisis "reliance interests are important considerations in property . . cases "); Leegin Creative Leather Prods., Inc. v. PSKS, Inc., 551 U.S. 877, 906 (2007) (quoting State Oil Co. v. Kahn, 522 U.S. 3, 20 (1997)) (noting that "reliance on a judicial opinion is a significant reason to adhere to it ... especially 'in cases involving property ... rights"”).
} 
our nation's history. For decades, the Supreme Court interpreted the amendment as only protecting a collective right to "keep and bear" weapons for the limited purpose of military service, not an individual right to keep and bear weapons as a general matter. Thus, in the 1939 decision of United States v. Miller, ${ }^{22}$ the Court stressed that the amendment was adopted "[w]ith obvious purpose to assure the continuation and render possible the effectiveness" of militia forces. ${ }^{23}$ Consistent with this interpretation, the Court had never struck down any law regulating weapons as unconstitutional.

The Roberts Court revolutionized this field in its 2008 decision in District of Columbia v. Heller, ${ }^{24}$ holding for the first time that the Second Amendment guarantees "the individual right to possess and carry weapons" without any necessary connection to militia service. ${ }^{25}$ Heller, who wished to keep a handgun in his home for personal defense, challenged a District of Columbia statute which effectively prohibited the possession of such weapons. ${ }^{26}$ Joined by Chief Justice Roberts and Justices Kennedy, Thomas, and Alito, Justice Scalia wrote the majority opinion from an originalist perspective. ${ }^{27} \mathrm{He}$ developed a comprehensive textual and historical analysis to justify the conclusion that the amendment recognized an individual right. In his view, there was "no doubt ... that the Second Amendment conferred an individual right to keep and bear arms." 28

Scalia conceded that the right was not unlimited; it "was not a right to keep and carry any weapon whatsoever in any manner whatsoever and for whatever purpose," 29 just as the First Amendment did not allow citizens to speak for any purpose. ${ }^{30}$ He suggested that certain existing prohibitions on the possession of weapons by the mentally ill or regulations on the commercial sale of weapons might well be constitutional. $^{31}$ But he reasoned that the District of Columbia ban was unconstitutional because it prohibited possession of a handgun in "the

\footnotetext{
22. 307 U.S. 174 (1939).

23. Id. at 178 .

24. 554 U.S. 570 (2008). For an overview of Heller, see Symposium, Gun Control and the Second Amendment: Developments and Controversies in the Wake of District of Columbia v. Heller and McDonald v. Chicago, 39 FordHAM URB. L.J. 1339 (2012).

25. Heller, 554 U.S. at 592.

26. Id. at $574-75$.

27. Id. at 572 .

28. Id. at 595 .

29. Id. at 626

30. Id. at 595

31. Id. at $626-27$.
} 
home, where the need for defense of self, family, and property is most acute., ${ }^{32}$

Two years later, in McDonald v. City of Chicago, the Court held that the Second Amendment was incorporated into the concept of due process in the Fourteenth Amendment, and thus applied to the states. ${ }^{33}$ Justice Alito's majority opinion characterized Heller as protecting "the right to keep and bear arms for the purpose of self-defense." 34 Largely relying on the historical analysis in Heller, it found the right to be "deeply rooted" in the nation's history ${ }^{35}$ and "among those fundamental rights necessary to our system of ordered liberty." $" 36$ Accordingly, the majority seemed to hold that the Second Amendment was a "liberty" within the meaning of the Due Process Clause of the Fourteenth Amendment. ${ }^{37}$ While this approach would be consistent with the rationale used in past incorporation decisions, the classification was not expressly used in McDonald.

Should the individual right recognized in Heller and McDonald be characterized as a property right? As Justice Stevens observed in his McDonald dissent, "in some respects the substantive right at issue [to keep and bear arms] may be better viewed as a property right," ${ }^{38}$ rather than as a "liberty." He noted that "[i]nterests in the possession of chattels have traditionally been viewed as property interests subject to definition and regulation by the States." 39 In turn, Justice Scalia retorted: "Never mind that the right to bear arms sounds mighty like a liberty; and never mind that the 'liberty clause' is really a Due Process Clause which explicitly protects "property." 40 Here, Scalia seemed to straddle the

\footnotetext{
32. Id. at 628 .

33. 561 U.S. 742, 791 (2010). For an overview of McDonald, see Symposium, supra note 24.

34. McDonald, 561 U.S. at $749-50$.

35. Id. at 768 (quoting Washington v. Glucksberg, 521 U.S. 702, 721 (1997)).

36. Id. at 778 .

37. The Fourteenth Amendment provides, in pertinent part: "[N]or shall any State deprive any person of life, liberty, or property, without due process of law." U.S. CONST. amend. XIV, $§ 1$.

38. McDonald, 561 U.S. at 894 (Stevens, J., dissenting).

39. Id.

40. Id. at 799 n.6 (Scalia, J., concurring). Scalia cited his concurring opinion in United States v. Carlton, 512 U.S. 26 (1994), to support this argument. There he lamented that the Court's majority recognized only "liberty" interests as fundamental rights under substantive due process analysis, even though the Due Process Clause encompasses both "liberty" and "property." Id. at 4142 (Scalia, J., concurring). An example is Moore v. City of East Cleveland, 431 U.S. 494 (1977), where the Court invalidated a city housing ordinance that restricted which family members could live in a home. In Moore, the Court viewed the ordinance as interfering with a liberty interest ("freedom of personal choice in matters of ... family life") rather than a property right (the right to use a home as the owner wishes). Id. at 499 (quoting Cleveland Bd. of Educ. v. LaFleur, 414 U.S. $632,639-40(1974))$.
} 
fence, arguing first that the protected interest is a "liberty" under the clause, but then suggesting it alternatively could be covered under the "property" strand.

In a functional sense, the individual right to keep and bear arms can be described as a property right, as Stevens suggested. Over seventy years ago, the Supreme Court endorsed the conventional view that property rights in a physical object are the rights to "possess, use and dispose of it." 41 Four years after McDonald, the Court applied the bundle-of-rights analysis to a firearm in Henderson v. United States. ${ }^{42}$ There, a federal law made it illegal for Henderson, a convicted felon, to "possess" a firearm, but the government interpreted the law as also barring Henderson from transferring his firearms to a friend. ${ }^{43}$ Justice Kagan's unanimous opinion found for Henderson, explaining that the statute interfered with only "a single incident of ownership-one of the proverbial sticks in the bundle of property rights-by preventing the felon from knowingly possessing his ... guns." 44 It reasoned that the government had "conflate[d] the right to possess a gun with another incident of ownership, which [the statute] does not affect: the right merely to sell or otherwise dispose of that item." 45 Viewed from this bundle-of-sticks framework, the right to "possess and carry" weapons recognized in Heller seems indistinguishable from the traditional rights to "possess and use" any tangible object.

The categorization of the right to possess and carry weapons as either a liberty right or a property right has consequences. As Justice Stevens noted, property rights in chattels have traditionally been defined and regulated by state law. ${ }^{46}$ If the Second Amendment right recognized in Heller is viewed in property terms, then states may have greater freedom to regulate the right. Conversely, if the right is conceptualized as a liberty interest, this might narrow its scope in certain situations. One question, for example, is whether Heller protects the right to own particular weapons (a property right) or merely a general right to own weapons (a liberty right). ${ }^{47}$

\footnotetext{
41. United States v. Gen. Motors Corp., 323 U.S. 373, 378 (1945).

42. 135 S. Ct. 1780 (2015).

43. Id. at 1783 .

44. Id. at 1784 .

45. Id. at 1785 .

46. McDonald v. City of Chicago, 561 U.S. 742, 894 (2010) (Stevens, J., dissenting).

47. See John L. Schwab \& Thomas G. Sprankling, Houston, We Have A Problem: Does the Second Amendment Create a Property Right to a Specific Firearm?, 112 COLUM. L. REV. Sidebar 158 (2012).
} 
Ultimately, it may be appropriate to view the Second Amendment as creating a sort of super-property right that enjoys greater immunity from state regulation than property rights arising under state law because of its constitutional genesis-like the specialized property rights arising under the Third and Fourth Amendments. At a minimum, however, the Roberts Court has revolutionized this area by creating a property-like right that is akin to the specific property rights protected by the Constitution.

\section{Fourth Amendment}

Traditionally, the definition of a "search" within the meaning of the Fourth Amendment was tied to common law trespass. Under this property-based approach, if the entry of government officials onto real property for the purpose of obtaining information constituted a trespass, it was deemed to be a Fourth Amendment search. ${ }^{48}$ The historic test, then, focused on places, not people. ${ }^{49}$ Almost fifty years ago, the Court appeared to reject this approach in the 1967 decision of Katz v. United States, holding instead that a search occurred when government efforts to obtain information violated a person's reasonable expectation of privacy. ${ }^{50} \mathrm{Katz}$ essentially reversed the historic test by focusing on people, not places.

For almost five decades, it was generally understood that the Katz doctrine had replaced the historic test. But as part of its propertization campaign, the Roberts Court has resurrected the property approach by holding that the Fourth Amendment carves out certain constitutionally protected areas; entry into these areas is deemed to be a search, regardless of whether the owner or occupant has a reasonable expectation of privacy. ${ }^{51}$

The groundbreaking decision was United States v. Jones, ${ }^{52}$ where police attached a small global positioning tracking system to a car "owned" by Jones, ${ }^{53}$ who was under suspicion for narcotics trafficking. ${ }^{54}$

\footnotetext{
48. See, e.g., Berger v. New York, 388 U.S. 41, 51-52, 57, 59 (1967).

49. See id.

50. See 389 U.S. 347, 350-53 (1967).

51. For detailed analysis of decisions in this area, see Carol A. Chase, Cops, Canines, and Curtilage: What Jardines Teaches and What It Leaves Unanswered, 52 Hous. L. REV. 1289 (2015); see also Fabio Arcila, Jr., GPS Tracking Out of Fourth Amendment Dead Ends: United States v. Jones and the Katz Conundrum, 91 N.C. L. REV. 1 (2012).

52. 132 S. Ct. 945 (2012).

53. The car was registered in the name of Jones' wife, but was exclusively driven by Jones; the Court noted that "[i]f Jones was not the owner he had at least the property rights of a bailee." Id.
} 
The trial court denied Jones' motion to suppress the evidence obtained through the GPS device on the basis that it was the product of a warrantless search, and he was convicted. ${ }^{55}$ Chief Justice Roberts and Justices Scalia, Kennedy, Thomas, and Sotomayor ruled that this conduct constituted a search-and therefore violated the Fourth Amendment-based on an originalist approach. ${ }^{56}$ Writing for the majority, Scalia relied almost exclusively on real property authorities, even though a car is classified as a chattel. ${ }^{57}$ He stressed that " $[t]$ he Government physically occupied private property for the purpose of obtaining information," which "would have been considered a 'search' within the meaning of the Fourth Amendment when it was adopted." With little analysis, he then asserted that the Katz test had been "added to, not substituted for, the common-law trespassory test." approach, a Fourth Amendment search occurs where "the Government obtains information by physically intruding on a constitutionally protected area." 60 "What we apply," Scalia concluded, "is an 18thcentury guarantee against unreasonable searches, which we believe must provide at a minimum the degree of protection it afforded when it was adopted." ${ }^{61}$ Concurring in the result, Justice Alito criticized the revival of the property test, noting the irony of using "18th-century tort law" to deal with a "21st-century surveillance technique." 62

One year later, the Court revisited the scope of Jones in Florida $v$. Jardines. ${ }^{63}$ The case arose when police officers took a drug-sniffing dog to the front porch of Jardines' home; based on the dog's indication that drugs were present, the police obtained a search warrant and found marijuana plants inside. ${ }^{64}$ The trial court accepted Jardines' argument that the use of the dog constituted a Fourth Amendment search, but the

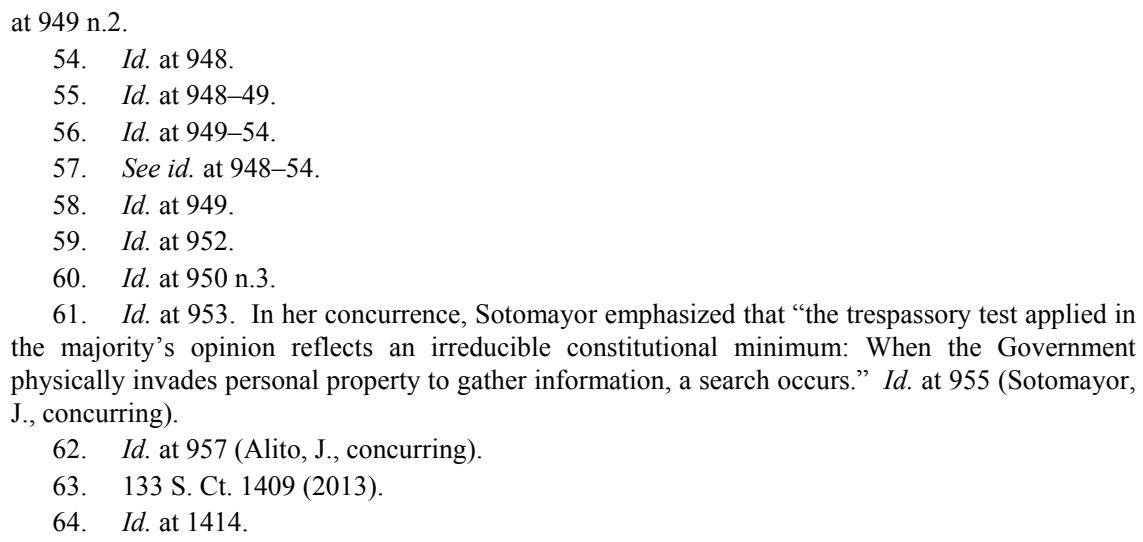


state appellate court rejected the claim. ${ }^{65}$ The Supreme Court disagreed, finding that the police conduct did constitute a search. ${ }^{66}$

Writing for the majority-which included Justices Thomas, Ginsburg, Sotomayor, and Kagan-Justice Scalia began by characterizing Jones as holding that a Fourth Amendment search occurs when the government obtains information by physically intruding "on... houses, papers, or effects," meaning of "constitutionally protected area." Under this principle, the case was "a straightforward one," 68 because the front porch of a home was part of the curtilage- "the area "immediately surrounding and associated with the home." "69 Scalia pointed out that the curtilage has long been regarded as part of the home for Fourth Amendment purposes, citing authorities which included Blackstone's famous 1769 treatise, Commentaries on the Laws of England. ${ }^{70}$ He distinguished the curtilage from a privately-owned open field because "such fields are not enumerated in the Amendment's text." Alito, did not challenge the use of the Jones property test as a general matter, but instead argued that because members of the public had an implied license to approach the front door of a home, no trespass had occurred. $^{72}$

In sum, the Roberts Court transformed Fourth Amendment jurisprudence in Jones and Jardines by resurrecting the property-based approach. Notably, all eight current Justices have endorsed this approach. ${ }^{73}$ These decisions significantly enlarge the Fourth Amendment protection for property owners: the entry of officials into a "constitutionally protected area" for the purpose of obtaining information is a Fourth Amendment "search" even if the owner had no reasonable expectation of privacy in the area. In his Jardines opinion, Scalia commented that "[o]ne virtue of the Fourth Amendment's property-rights

\footnotetext{
65. Id. at 1413 .

66. Id. at $1417-18$.

67. Id. at 1414 (citing Jones, 132 S. Ct. at 950, n.3).

68. Id.

69. Id. (quoting Oliver v. United States, 466 U.S. 170, 180 (1984)).

70. Id. at $1414-15$ (citing 4 William Blackstone, COMMENTARIES $* 223, * 225$ ).

71. Id. at 1414 (citing Hester v. United States, 265 U.S. 57 (1924)).

72. See id. at 1420-24 (Alito, J., dissenting).

73. Six current Justices approved this test in Jones or Jardines; and eight current Justices later joined the unanimous opinion in Grady v. North Carolina, 135 S. Ct. 1368 (2015) (per curiam), which extended the test by holding that a satellite-based monitoring device attached to a person's body was a "search," despite the lack of any expectation of privacy.
} 
baseline is that it keeps easy cases easy." ${ }^{, 74}$ But does it?

The Jones-Jardines duo suggests that the Amendment now encompasses a broad range of areas that are open to public view including: (a) the fenced or unfenced front yard, side yard, and backyard of a detached single-family home; (b) the airspace over a home; (c) outbuildings near a home, such as a garage, shed, or barn; and (d) the exterior and interior of airplanes, boats, cars, and trucks. Moreover, readoption of the property approach raises difficult questions about how it applies to forms of group housing other than the paradigmatic detached single-family house, such as a shared hallway or common recreational facilities in a townhouse or condominium development. In short, these decisions seem to open the door to a plethora of future cases which will test the outer limits of the property approach. ${ }^{75}$

\section{Fifth Amendment}

The Takings Clause of the Fifth Amendment has been a major property rights battlefield for decades. The multi-factor test for determining a regulatory taking, as adopted by the Burger Court in the landmark 1978 decision of Penn Central Transportation Co. v. City of New York, ${ }^{76}$ was criticized by some as failing to adequately protect private property against government action. An initial effort to limit the Penn Central approach came four years later when the Court held in Loretto v. Teleprompter Manhattan CATV Corp. ${ }^{77}$ that a "permanent physical occupation" of an owner's property by government or authorized by government is a taking, regardless of the government purpose it serves. $^{78}$

The Rehnquist Court continued to erode the Penn Central standard in later terms, particularly by adopting two new bright-line or "categorical" tests that broadened the regulatory takings doctrine. In Lucas v. South Carolina Coastal Council, ${ }^{79}$ the Court held that a regulation which denies an owner "all economically beneficial or

74. Jardines, $133 \mathrm{~S}$. Ct. at 1417.

75. See, e.g., City of Los Angeles v. Patel, 135 S. Ct. 2443 (2015) (holding that a city ordinance which required hotel operators to make their registries available to police officers without a warrant violated the Fourth Amendment).

76. 438 U.S. 104 (1978).

77. 458 U.S. 419 (1982).

78. Id. at 441 .

79. 505 U.S. 1003 (1992). 
productive use of land" ${ }^{\prime 80}$ is a compensable taking unless it is justified by "background principles of the State's law of property and nuisance." 81 And in the twin decisions of Nollan v. California Coastal Commission ${ }^{82}$ and Dolan v. City of Tigard ${ }^{83}$ the Court established a second categorical test: the government's exaction of a right in real property in return for a discretionary land use approval is a taking if (a) there is no "essential nexus" between the exaction and a legitimate state interest ${ }^{84}$ or (b) the exaction is not roughly proportional to the impact of the proposed project. $^{85}$

The first Takings Clause case to reach the Roberts Court, Wilkie v. Robbins, ${ }^{86}$ was decided in $2007 .{ }^{87}$ The case is noteworthy because the Court refused to create a new categorical test, in contrast to its later decisions which expand the scope of the Takings Clause. Robbins, a Wyoming rancher, asserted that Bureau of Land Management officials had engaged in a "campaign of harassment and intimidation" against him in order to obtain an easement across his land, asserting damage claims under both Bivens v. Six Unknown Named Agents of Federal Bureau of Narcotics ${ }^{88}$ and the Racketeer Influenced and Corrupt Organizations Act. ${ }^{89}$ The district court refused to dismiss these claims, and the Tenth Circuit affirmed. ${ }^{90}$ Before the Supreme Court the key issue was whether a Bivens claim should be recognized, though Robbins' brief framed the issue more broadly: "[C]an government officials avoid the Fifth Amendment's prohibition against taking property without just compensation by using their regulatory powers to harass, punish, and coerce a private citizen into giving the Government his property without payment?"91

Taking a pragmatic view—notably absent in later Roberts Court

80. Id. at 1015 (citing Agins v. City of Tiburon, 447 U.S. 255, 260 (1980), abrogated by Lingle v. Chevron U.S.A. Inc., 544 U.S. 528 (2005)).

81. Id. at 1029 .

82. 483 U.S. 825 (1987).

83. 512 U.S. 374 (1994).

84. Nollan, 483 U.S. at 837.

85. Dolan, 512 U.S. at 391.

86. 551 U.S. 537 (2007).

87. See generally Laurence H. Tribe, Death by a Thousand Cuts: Constitutional Wrongs Without Remedies After Wilkie v. Robbins, 2007 CATO Sup. CT. REV. 23.

88. 403 U.S. 388 (1971).

89. Wilkie, 551 U.S. at 541, 547-49. The Racketeer Influenced and Corrupt Organizations Act is codified at 18 U.S.C. $\S \S 1961-1968$ (2012).

90. Wilkie, 551 U.S. at 548-49.

91. Id. at 556 n. 8 (quoting Brief for Respondent at 21, Wilkie v. Robbins, 551 U.S. 537 (2007) (No. 06-219)). 
property decisions-Justice Souter's majority opinion sidestepped the takings issue and refused to extend the Bivens approach. ${ }^{92}$ Joined by Chief Justice Roberts and Justices Scalia, Kennedy, Thomas, Breyer, and Alito, Souter reasoned that Robbins had adequate avenues to pursue his claims and, moreover, that it would be difficult to define a workable cause of action. ${ }^{93}$ He stressed that government in its capacity as a landowner was entitled "to drive a hard bargain" 94 with its neighbors, making it impossible to determine when it "demanded too much and went too far." 95 Interestingly, it was Justices Ginsburg and Stevens, representing the more liberal wing of the Court, who argued for an expansive reading of the Fifth Amendment: "The Fifth Amendment... must be read to forbid government action calculated to acquire private property coercively and cost free, and measures taken in retaliation for the owner's resistance to uncompensated taking." 96

But three subsequent Roberts Court decisions ${ }^{97}$ have significantly broadened the scope of the Takings Clause: Stop the Beach Renourishment, Inc. $v$. Florida Department of Environmental Protection, ${ }^{98}$ Koontz v. St. Johns River Water Management District, ${ }^{99}$ and Horne v. Department of Agriculture. ${ }^{100}$ Taken together, these decisions further weaken the Penn Central approach in favor of sweeping categorical rules which make it more likely that government action will be deemed a taking.

The 2010 decision in Stop the Beach Renourishment is important because it signals that a majority of the current Court agrees that a judicial decision which eliminates or substantially changes even a minor property right would violate the Constitution-a substantial expansion of

92. Id. at 567-68. Part of the explanation for the outcome in Wilkie was the continued antipathy of Justices Scalia and Thomas toward creating any new cause of action based on Bivens, as reflected in Thomas' concurrence, which Scalia joined. Id. at 568 (Thomas, J., concurring).

93. Id. at 555-62 (majority opinion).

94. Id. at 558 .

95. Id. at 557

96. Id. at 584 (Ginsburg, J., concurring).

97. The only other Takings Clause decision by the Roberts Court, Arkansas Game \& Fish Commission v. United States, 133 S. Ct. 511 (2012), broke little new ground. In an opinion written by Justice Ginsburg, all eight participating Justices rejected the assertion that temporary government-induced flooding was automatically exempt from Takings Clause liability. Id. at 522. This was an unsurprising result given the Court's prior decisions.

98. 560 U.S. 702 (2010). For an overview of Stop the Beach Renourishment, see Laura S. Underkuffler, Judicial Takings: A Medley of Misconceptions, 61 SYRACUSE L. REV. 203 (2011).

99. 133 S. Ct. $2586(2013)$.

100. 135 S. Ct. 2419 (2015). 
the legal shelter provided to owners. ${ }^{101}$ Chief Justice Roberts and Justices Thomas and Alito would reach this result through the Takings Clause, ${ }^{102}$ while Justices Kennedy and Sotomayor would do so through the Due Process Clause. ${ }^{103}$

Stop the Beach Renourishment was decided against the backdrop of three key precedents. In its landmark Penn Central decision, the Court held that in determining whether government action has effected a taking of real property a court should consider the "extent of the interference with rights in the parcel as a whole," rather than simply the portion of the property directly affected by the particular action. ${ }^{104}$ But a year later, in Kaiser Aetna v. United States, the Court found a compensable taking when the U.S. Army Corps of Engineers ruled that the owner's property was subject to the federal navigational servitude. ${ }^{105}$ The majority opinion explained that there were a "number of expectancies embodied in the concept of 'property'-expectancies that, if sufficiently important, the Government must condemn and pay for before it takes over the management of the landowner's property."106 Because of the traditional importance of the right to exclude, "one of the most essential sticks in the bundle of rights that are commonly characterized as property," the Court concluded that a taking had occurred even though the owner retained all of the other sticks in the metaphorical bundle. ${ }^{107}$ The same theme that a taking could be found when a single important property right was taken resurfaced eight years later in Hodel v. Irving, where a federal regulation prevented Native Americans from devising extremely small fractional interests in Indian trust lands, as part of an effort to combat excessive fragmentation of property rights. ${ }^{108}$ The Court again stressed the importance of the right, observing that "the right to pass on property-to one's family in particular-has been part of the Anglo-American legal system since feudal times."

In contrast to these decisions, Stop the Beach Renourishment involved two minor property rights. ${ }^{110}$ The petitioners, owners of ocean-

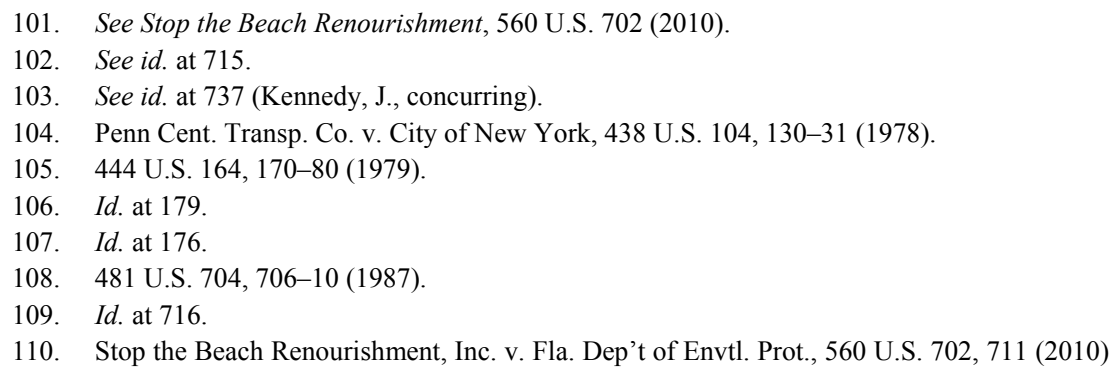


front property, asserted that a decision of the Florida Supreme Court which rejected their lawsuit against the state's beach restoration project had eliminated-and thus illegally "taken"- two common law rights that were akin to easements: "the right to receive accretions to their property" from the ocean and "the right to have the contact of their property with the water remain intact." "111 eight participating Justices ruled for the state, on the basis that the petitioners had never held such rights and, therefore, were not injured by the Florida decision. ${ }^{12}$

But Chief Justice Roberts and Justices Scalia, Thomas, and Alito reached well beyond this point to assert the novel claim that the Takings Clause encompassed the taking of property by judicial action, in addition to executive and legislative action. ${ }^{113}$ Justice Scalia's plurality opinion first asserted that the Court's precedents recognized an additional categorical test-that "States effect a taking if they recharacterize as public property what was previously private property." 114 He then explained that this test should apply to judicial action because (a) there was "no textual justification" in the Takings Clause for holding that the existence of such a taking should vary "according to the branch of government effecting the expropriation""115 and (b) "[i]t would be absurd to allow a State to do by judicial decree what the Takings Clause forbids it to do by legislative fiat." ${ }^{116}$ The logical implication of this view, of course, is that federal courts have the ultimate power to determine state property law, not state courts. ${ }^{117}$ Although the other four Justices refused to embrace the judicial takings theory, Justices Kennedy and Sotomayor argued that substantive due process could provide similar protection for

(citing Save Our Beaches, Inc. v. Fla. Dep't of Envtl. Prot., 27 So. 3d 48, 58 (Fla. Dist. Ct. App. 2006), quashed sub nom. Walton Cnty. v. Stop the Beach Renourishment, Inc., 998 So. 2d 1102 (Fla. 2008), aff'd sub nom. Stop the Beach Renourishment, 560 U.S. 702).

111. Stop the Beach Renourishment, 560 U.S. at 711-12.

112. See id. at 733; id. at 742 (Kennedy, J., concurring).

113. See id. at $713-15$ (plurality opinion).

114. Id. at 713. The plurality opinion observed that this test was part of the "general principles of our takings jurisprudence." Id.

115. Id. at 714. This textual analysis has limited value, however, since most scholars agree that the Takings Clause was originally intended only to apply to physical takings, not regulatory takings. See, e.g., William Michael Treanor, The Original Understanding of the Takings Clause and the Political Process, 95 Colum. L. Rev. 782 (1995); see also Lucas v. S.C. Coastal Council, 505 U.S. 1003, 1028 n.15 (1992) ("[E]arly constitutional theorists did not believe the Takings Clause embraced regulations of property at all.").

116. Stop the Beach Renourishment, 560 U.S. at 714.

117. In fact, the Supreme Court sometimes opines on general principles of property law without citing state-specific authorities. See, e.g., Marvin M. Brandt Revocable Tr. v. United States, 134 S. Ct. 1257, 1265-66 (2014) (discussing law relating to easements and reversionary interests). 
property owners. ${ }^{118}$ Without citing direct authority, they reasoned that a judicial decision which "eliminates or substantially changes established property rights, which are a legitimate expectation of the owner, is 'arbitrary or irrational' under the Due Process Clause." 119

Similarly, the plurality opinion seemed to assume that the loss of even one minor property right would require compensation under the Takings Clause. Rather than explaining why the two easement-like rights at issue were important enough to satisfy the Kaiser Aetna and Hodel standards, it merely asserted that the "deprivation of an established property right" would be a taking, even if an owner retained virtually all other property rights. ${ }^{120}$ Even assuming arguendo that the Florida Supreme Court decision did eliminate two easement-like rights, the owners still held fee simple absolute title to their respective parcels, with all of the core property rights traditionally associated with the metaphorical bundle of sticks, including the rights to possess, use, exclude, and transfer. Thus, the extent of the interference with the owners' rights was minor and would not rise to the level of a taking under either Kaiser Aetna or Hodel.

Justices Kennedy and Sotomayor, who concurred in the result without joining the plurality rationale, appeared to agree that even the loss of a minor property right would violate the Constitution, though not the Takings Clause. ${ }^{121}$ Their concurrence noted that the elimination or substantial change of "an established property right" could "be set aside as a deprivation of property" under the Due Process Clause-without any discussion of the importance of the right. ${ }^{122}$

In sum, five current Justices endorse the view that a judicial decision which eliminates or substantially changes even a minor property right would violate the Constitution under some circumstances. At best, this rule is too vague to be meaningful. There is no clear definition of what constitutes a "property right," much less any understanding about what constitutes a "substantial" change in such a right. Although there is widespread agreement about the content of what may be called major property rights—-such as the classic rights to possess, use, exclude, and

\footnotetext{
118. Stop the Beach Renourishment, 560 U.S. at 735-38 (Kennedy, J., concurring).

119. Id. at 737 (citing Lingle v. Chevron U.S.A., Inc., 544 U.S. 528, 542 (2005)). But see Hughes v. Washington, 389 U.S. 290, 296 (1967) (Stewart, J., concurring) (observing that a judicial decision which "constitutes a sudden change in state law, unpredictable in terms of the relevant precedents" would be a taking of property without due process of law).

120. Stop the Beach Renourishment, 560 U.S. at 726 n.9.

121. Id. at 735 (Kennedy, J., concurring).

122. Id.
} 
transfer-there is a host of relatively minor entitlements accompanying an estate which might or might not be classified as distinct "property rights," depending on how finely entitlements are sliced. For example, some states have altered the adversity element of adverse possession by judicial decisions which replace the good faith test with the objective test. ${ }^{123}$ If an owner's entitlement to defeat an adverse possession claim by relying on the stricter good faith test is viewed as a type of "property right," then such a decision might be viewed as a "substantial change" to this right-which would entitle him to compensation from the state if he loses title to an adverse claimant under the objective test.

Three years later, Koontz v. St. Johns River Water Management District expanded the Nollan-Dolan rule by holding that it also applied to fees, not simply to real property exactions. ${ }^{124}$ Both Nollan and Dolan involved the narrow situation where a government entity demands one or more easements over an owner's real property in exchange for a discretionary land use approval. ${ }^{125}$ Neither decision considered whether the same rule would apply to fees imposed on new developments-such as payments to offset the impact of a new residential subdivision on a municipal library, park, or school-which are widely used by local governments to offset the cost of new infrastructure. By extending the Nollan-Dolan restrictions to fees, Koontz curbs the traditional discretion that local governments have enjoyed in land use planning and thereby enlarges the constitutional protection afforded to owners. ${ }^{126}$ Before Koontz it was widely believed that the Takings Clause did not apply to fees or other general monetary obligations.

In Koontz, a local district denied approval for Koontz's plan to fill his wetland parcel in preparation for a building project because he

123. See, e.g., Tioga Coal Co. v. Supermarkets Gen. Corp., 546 A.2d 1 (Pa. 1988). Under the good faith test, the adverse claimant must actually believe that she owns the land, while under the objective test the claimant's state of mind is irrelevant. See John G. SPRANKLInG, Understanding PROPERTY LAW 458 (3d ed. 2012).

124. 133 S. Ct. 2586, 2598-602 (2013). For an overview of Koontz, see Lee Anne Fennell \& Eduardo M. Peñalver, Exactions Creep, 2013 SuP. CT. REV. 287.

125. See Nollan v. Cal. Coastal Comm'n, 483 U.S. 825 (1987); Dolan v. City of Tigard, 512 U.S. 374 (1994).

126. Another aspect of Koontz merits mention: the majority's endorsement of externality theory. Advocates of the law and economics movement have long argued that land use regulation should be structured to achieve economic efficiency by requiring developers to internalize their negative externalities. In Koontz, a majority of the Court expressly endorsed this view for the first time: "Insisting that landowners internalize the negative externalities of their conduct is a hallmark of responsible land-use policy..." Koontz, $133 \mathrm{~S}$. Ct. at 2595 . In a broad sense, such internalization is the practical effect of the Nollan-Dolan approach. The intriguing issue is whether this view might affect other regulatory takings doctrines, such as the Lucas test. 
refused to agree to either of the two concessions the district suggested. ${ }^{127}$ One of the alternatives required that he pay for improvements to districtowned wetlands several miles from the project site. ${ }^{128}$ Lower state courts reasoned that this violated the Nollan-Dolan test due to the lack of both an essential nexus and rough proportionality. ${ }^{129}$ But the Florida Supreme Court reversed. ${ }^{130}$ It reasoned that the test did not apply to (a) a demand for money or (b) denial of a permit for the applicant's failure to make a requested concession to the district. ${ }^{131}$ Chief Justice Roberts and Justices Scalia, Kennedy, and Thomas joined Justice Alito's majority opinion which overturned the Florida decision on both bases. ${ }^{132}$

The backdrop for Koontz was the Court's 1998 decision in Eastern Enterprises v. Apfel, which involved a federal statute that required the former employers of retired miners to pay retroactively for their health care benefits. ${ }^{133}$ Four members of the Court held that the statute was a regulatory taking. ${ }^{134}$ While concurring with the result, Justice Kennedy disagreed with the plurality's rationale on the basis that the Takings Clause did not apply to a purely monetary obligation. ${ }^{135}$ He stressed that a "constant limitation" in past regulatory takings had been that "a specific property right or interest has been at stake." "136 In contrast, he observed, the statute at issue did not affect an "identified property interest," but merely required the performance of an act-a monetary payment that might come from any source. ${ }^{137}$

The Koontz majority attempted to distinguish Eastern Enterprises on the theory that the monetary obligation at issue "burdened petitioner's ownership of a specific parcel of land," and thus somewhat resembled a lien. ${ }^{138}$ It asserted that the "fulcrum this case turns on is the direct link between the government's demand and a specific parcel of real

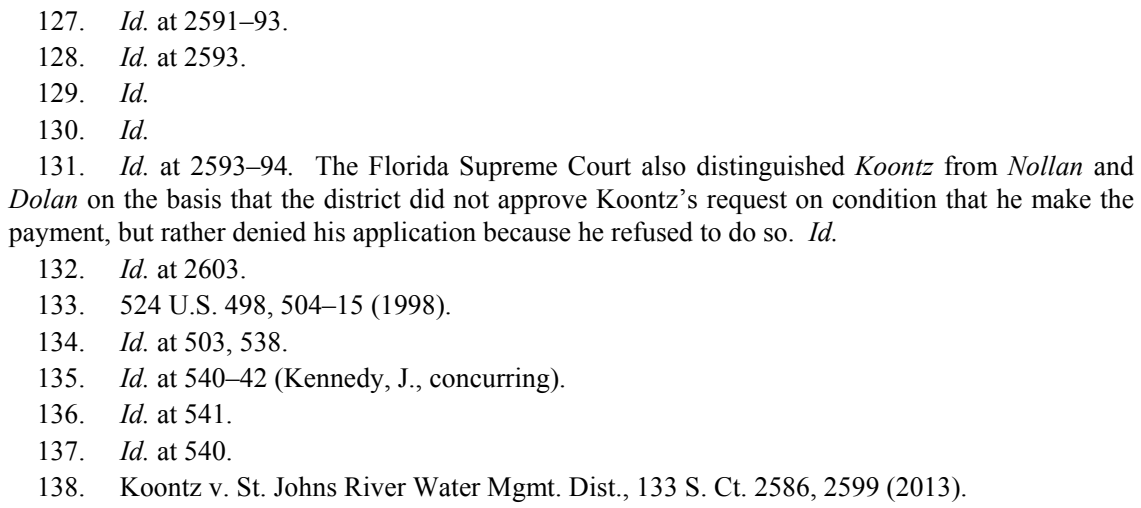


property."139 This distinction is unconvincing. A lien burdens a particular property in the sense that the property can ultimately be sold to satisfy the debt secured by the lien, which certainly was not the case in Koontz. Moreover, any "link" between the district's demand and Koontz's land is irrelevant. The point is that the district asked Koontz to pay a specific amount, which he could have obtained from any source-a bank account, lottery winnings, or a loan from a friend. Thus, the case did not involve a taking of an "identified property interest."

After Koontz, it is clear that the Nollan-Dolan test applies to monetary exactions in the land use context-despite the obvious difficulty of distinguishing between an unconstitutional exaction and a legitimate tax. But the outer limits of the Koontz approach are unclear. The majority observed that Koontz "does not ask us to hold that the government can commit a regulatory taking by directing someone to spend money."141 But because the majority's attempt to distinguish Eastern Enterprises is unconvincing, Koontz may well serve as a stepping stone toward a future decision which applies a Takings Clause analysis outside of the land use setting, potentially to any monetary demand made by government. ${ }^{142}$

Finally, the 2015 decision in Horne v. Department of Agriculture ${ }^{143}$ safeguards property rights by broadening the categorical test established in Loretto. ${ }^{144}$ Horne arose out of a program established by the Department of Agriculture to assist raisin growers by stabilizing the national price for raisins. ${ }^{145}$ It required each grower to physically set aside a certain portion of the crop, which the government could then sell, donate, or otherwise dispose of as appropriate to promote the raisin market; the government took title to these raisins. ${ }^{146}$ Each grower,

139. Id. at 2600 .

140. Id. at 2599 (quoting Eastern Enterprises, 524 U.S. at 540 (Kennedy, J., concurring)). Nonetheless, the Koontz majority noted that "this case does not implicate the question whether monetary exactions must be tied to a particular parcel of land in order to constitute a taking." $I d$. at 2600 n.2.

141. Id. at 2600 .

142. The second prong of Koontz was less controversial. As Justice Alito summarized, "[t]he principles that undergird our decisions in Nollan and Dolan do not change depending on whether the government approves a permit on the condition that the applicant turn over property or denies a permit because the applicant refuses to do so." Id. at 2595.

143. 135 S. Ct. 2419 (2015).

144. See id. at 2427-28; Loretto v. Teleprompter Manhattan CATV Corp., 458 U.S. 419 (1982). Horne also breaks new ground in defining the extent of constitutional protection for personal property. See infra discussion Section III.E.3.

145. Horne, 135 S. Ct. at 2424-25.

146. Id. at 2424 . 
however, was entitled to receive its proportionate share of net proceeds from such government sales. ${ }^{147}$ The Hornes refused to set aside any portion of their crop, and instead sued on a takings theory, arguing that these facts constituted a permanent physical occupation under Loretto. ${ }^{148}$ The Ninth Circuit rejected this claim, inter alia, viewing the government action as a use restriction, not a physical appropriation, because the Hornes were not completely divested of their property rights. ${ }^{149}$

Writing for a majority of eight Justices, Chief Justice Roberts concluded that the government action was a "clear physical taking" because the growers lost 'the entire 'bundle' of property rights in the appropriated raisins- 'the rights to possess, use and dispose of' them." Ironically, all parties agreed that the government could constitutionally prohibit the sale of raisins altogether without incurring takings liability. ${ }^{151}$ Yet even though "[a] physical taking of raisins and a regulatory limit on production may have the same economic impact on a grower," the majority explained that the Court's takings jurisprudence distinguished sharply between an appropriation and a mere regulation. ${ }^{152}$

Despite the majority's assertion that it was merely applying Loretto to a "clear physical taking," Horne enlarges the Loretto test. ${ }^{153}$ The Loretto approach was designed to deal with the extraordinary situation where the government eliminates all of an owner's property rights through a permanent physical occupation. ${ }^{154}$ In this narrow situation, the Loretto Court concluded, the policy reasons for the government action

\footnotetext{
147. Id.

148. Id. at 2424-25.

149. Id. at 2425 (citing Horne v. U.S. Dep't of Agric., 750 F.3d 1128, 1137 (9th Cir. 2014), rev'd, 135 S. Ct. 2419 (2015)). The Ninth Circuit also grounded its ruling on the theory that the Takings Clause accords less protection to personal property than to real property. Horne, 750 F.3d at 1139-40. The Supreme Court's rejection of this view is discussed in Section III.E.3.

150. Horne, 135 S. Ct. at 2428 (quoting Loretto v. Teleprompter Manhattan CATV Corp., 458 U.S. 419, 435 (1982)). Eight Justices joined in Parts I and II of the opinion, which are the portions at issue in the text discussion; only Justice Sotomayor dissented from these parts.

151. Horne, 135 S. Ct. at 2443 (Sotomayor, J., dissenting).

152. Id. at 2428 (majority opinion).

153. In addition, the majority opinion in Horne may hint at an expansion of the Penn Central test. The Penn Central Court stated that its prior decisions had identified "several factors" that had "particular significance" in determining whether a taking had occurred. Penn Cent. Transp. Co. v. City of New York, 438 U.S. 104, 124 (1978). It then listed three factors that should be considered in this process: the economic impact on the claimant, the extent of interference with reasonable investment-backed expectations, and "the character of the governmental action." Id. But Horne appears to characterize these factors merely as examples, not as an exclusive listing, when it notes that the Penn Central test requires consideration of factors "such as" the specified three. Horne, 135 S. Ct. at 2427 (emphasis added). A future Court might view this phrase as an opening that permits additional factors to be used in the Penn Central analysis.
}

154. See Loretto, 458 U.S. at 435-36. 
were irrelevant. $^{155}$ It stressed that such an occupation of real property "effectively destroys" an owner's traditional rights to possess, use, and dispose of property. ${ }^{156}$ In particular, the Court observed that such an occupation would "ordinarily empty the right [to dispose of property] of any value, since the purchaser will also be unable to make any use of the property."157 This rationale does not apply to the facts in Horne. Because the raisins were produced for commercial sale, only the right to dispose of them was relevant-and it was not destroyed, because the growers retained the right to share in proceeds from government sales. ${ }^{158}$ After Horne, even a government "occupation" which leaves an owner with substantial property rights would seem to be a per se taking, regardless of the underlying policy basis. ${ }^{159}$

Taken together, Stop the Beach Renourishment, Koontz, and Horne enlarge the meaning of the term "taken" as used in the Takings Clause, extending its scope to include new situations and making it more likely that government action will be deemed a compensable taking. In this area, the Roberts Court is following the lead of the Burger and Rehnquist Courts by broadening the categorical tests for assessing takings liability, thereby expanding the rights of property owners. Based on the first decade of its Takings Clause jurisprudence, there is every reason to believe that the Roberts Court will continue this expansion in future decisions.

\section{Home Protection}

The home is the embodiment of the American dream, a symbol of autonomy, family, privacy, and security. Thus, the law traditionally affords stronger protection to the home than to other forms of property. For example, the "house" is shielded against undue government intrusions by the text of the Third and Fourth Amendments; ${ }^{160}$ and past

\footnotetext{
155. See id. at 434-36.

156. Id. at 435 .

157. Id. at 436

158. Thus, Justice Sotomayor observed in her dissent that "it is not a per se taking if it does not result in the destruction of every property right." Horne, $135 \mathrm{~S}$. Ct. at 2438 (Sotomayor, J., dissenting).

159. Moreover, as the Ninth Circuit decision recognized, it was not clear in Horne that a physical taking had occurred because the Hornes never surrendered possession of the raisins to the government. Rather than trying to seize the raisins, the federal government initiated an enforcement action against the Hornes, which resulted in a monetary award against them for damages and civil penalties. Id. at 2424-25 (majority opinion). In this sense, Horne seems to expand the Loretto rule beyond physical seizures to what might be called unjustified demands for physical seizures.
}

160. See U.S. CONST. amend. III; id. amend. IV. 
Courts have often interpreted other constitutional amendments more broadly when the conduct in question occurs in a home. ${ }^{161}$

Yet the level of respect that the Supreme Court accords to the home varies over time. In the controversial decision of Kelo v. City of New London, for example, a majority of the Rehnquist Court concluded that homes were not entitled to more protection from eminent domain than other types of property. ${ }^{162}$ This sparked a stinging dissent from Justice O'Connor, who complained, inter alia, that "[n]othing is to prevent the State from replacing ... any home with a shopping mall." 163

The Roberts Court evidences unusually strong reverence for the home in both rhetoric and substance. Justice Souter expressed this sentiment in an early Roberts Court decision when he observed that "[w]e have . . lived our whole national history with an understanding of 'the ancient adage that a man's house is his castle [to the point that t] poorest man may in his cottage bid defiance to all the forces of the Crown." 164 Exalting the home as the most favored type of property, the Roberts Court has interpreted constitutional provisions and federal statutes in a manner that singles out houses for enhanced protection. This is particularly true in its key decisions interpreting the scope of the Second, Fourth, and Fourteenth Amendments. ${ }^{165}$ All eight current Justices have joined in decisions containing broad language that extols the importance of the home.

The Court's landmark 2008 decision in District of Columbia v. Heller, interpreting the Second Amendment to create a personal right to bear arms, cannot be separated from the factual context in which it arose:

161. See, e.g., Stanley v. Georgia, 394 U.S. 557 (1969) (holding that the First Amendment barred the government from prosecuting a person for possession of obscenity within a home, but not elsewhere); Moore v. City of East Cleveland, 431 U.S. 494 (1977) (holding that the Fourteenth Amendment prevented city from enforcing an ordinance that restricted the categories of relatives who could live in a home); see also D. Benjamin Barros, Home as a Legal Concept, 46 SANTA Clara L. Rev. 255 (2006).

162. 545 U.S. 469 (2005).

163. Id. at 503 (O'Connor, J., dissenting).

164. Georgia v. Randolph, 547 U.S. 103, 115 (2006) (quoting Miller v. United States, 357 U.S. 301, 307 (1958)).

165. Another example is Lozman v. City of Riviera Beach, 133 S. Ct. 735 (2013), where the Court rejected the argument that a floating home was a "vessel" under the Federal Maritime Lien Act, 46 U.S.C. § 31342 (2012), and thus subject to a maritime lien. Lozman, 133 S. Ct. at 739-41. It noted that the policy justification for imposing such a lien-the risk that a vessel owner could avoid creditors-was absent, since the floating home had no propulsion system, and the owner "cannot easily escape liability by sailing away in his home." Id. at 743-44. The Court also acknowledged that statutes in Florida and certain other jurisdictions treat floating homes "like ordinary land-based homes rather than like vessels." Id. at 744. 
the plaintiff's desire to keep a handgun in his home for self-defense. ${ }^{166}$ The first line in Justice Scalia's majority opinion focused on this point: "We consider whether a District of Columbia prohibition on the possession of usable handguns in the home violates the Second Amendment to the Constitution." ${ }^{167}$ In striking down the statute, the majority emphasized that the prohibition "extends, moreover, to the home, where the need for defense of self, family, and property is most acute." 168

Two years later, the Court ruled in McDonald v. City of Chicago that the Fourteenth Amendment incorporated the "Second Amendment right recognized in Heller" against the states in another case where owners sought to keep handguns in their homes. ${ }^{169}$ Notably, Justice Alito's majority opinion characterized Heller as holding that "the Second Amendment protects the right to possess a handgun in the home for the purpose of self-defense," outside of the home. The possession of handguns for home defense, then, was the central justification for abandoning the traditional view that the Second Amendment only applied to the operation of militias. ${ }^{171}$

The Fourth Amendment jurisprudence of the Roberts Court reflects a similar shift toward shielding the home. The Court applied the Katz privacy-based test in the 2006 decision of Georgia v. Randolph, where the issue was whether police could conduct a warrantless search of a home where one co-occupant consented to the search, but another cooccupant objected. ${ }^{172}$ Yet in doing so it began the process of circling back to the traditional property-based test which provided greater protection for homes and the surrounding curtilage. Justice Souter's majority opinion, joined by Justices Stevens, Kennedy, Breyer, and Ginsburg, stressed that the determination of reasonableness in Fourth Amendment consent cases was closely tied to "widely shared social expectations," which were "naturally enough influenced by the law of property, but not controlled by its rules." "173 Stressing the "centuries-old

\footnotetext{
166. 554 U.S. 570, 575-76 (2008).

167. Id. at 573 (emphasis added).

168. Id. at 628 (emphasis added).

169. 561 U.S. 742, 750, 791 (2010).

170. Id. at 791 (emphasis added).

171. For example, the Court denied a petition for a writ of certiorari in Friedman v. City of Highland Park, 136 S. Ct. 447 (2015), even though there the Seventh Circuit interpreted Heller as applying only to handguns kept in the home.

172. 547 U.S. 103, 106-08 (2006).

173. Id. at 111 .
} 
principle of respect for the privacy of the home,"174 the Court found "no recognized authority in law or social practice" 175 which allowed one cooccupant of a home to "open the door to a third party" objection of another co-occupant and, accordingly, held that the search was illegal. ${ }^{177}$

The Court's return to the property-based approach in United States $v$. Jones $^{178}$ and Florida v. Jardines ${ }^{179}$ restricts warrantless home searches, thus enlarging the rights of home owners and occupants. The six current Justices who joined one or both opinions-Chief Justice Roberts and Justices Kennedy, Thomas, Sotomayor, Ginsburg, and Kagan-thereby endorsed the broad pro-home language that they contain. ${ }^{180}$ Although the property at issue in Jones was a vehicle, the Court's justification for returning to the property-based approach was largely based on real property law. ${ }^{181}$ It cited an eighteenth-century English decision for the proposition that "[o]ur law holds the property of every man so sacred, that no man can set his foot upon his neighbour's close without his leave; if he does he is a trespasser." 182 Thus, an improper search would occur if officials intruded on a "constitutionally protected area," 183 such as the "curtilage of a home.", 184

Jardines, in turn, extended the property-based Jones approach to a home, where police brought a drug-sniffing dog to an owner's porch in an effort to search for marijuana. ${ }^{185}$ Although the government argued that the owner had no reasonable expectation of privacy on his front porch and thus that the entry was legal under Katz, the Court held that the police conduct violated the Fourth Amendment because it took place "in a constitutionally protected area." 186 The majority opinion explained that "when it comes to the Fourth Amendment, the home is first among

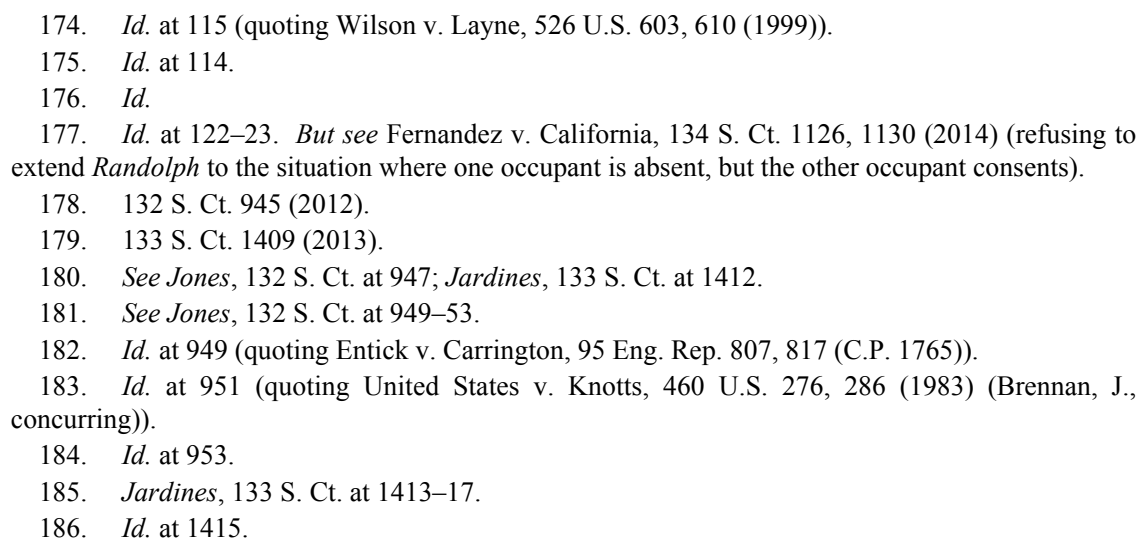


equals," because the heart of the Amendment is a person's right to "retreat into his own home and there be free from unreasonable governmental intrusion." 187 And the curtilage, the area immediately surrounding the home which included the porch, is similarly protected. ${ }^{188}$

The same orientation is evident in Jones v. Flowers, which was decided under the Due Process Clause of the Fourteenth Amendment. ${ }^{189}$ The broad issue was whether due process required a government entity to take additional steps to provide notice to a property owner when its mailed notices of a tax sale were returned as undeliverable. ${ }^{190}$ Writing for the Court, Chief Justice Roberts emphasized the fact that the property involved was a home: "In this case, we evaluate the adequacy of notice prior to the State extinguishing a property owner's interest in a home."191 When viewed within this framework, the Court concluded that the notice was insufficient. ${ }^{192}$ It doubted that "a person who actually desired to inform a real property owner of an impending tax sale of a house he owns would do nothing" when a mailed notice was returned unclaimed. ${ }^{193}$ And it reasoned that a sender of a returned letter would normally try to resend it, especially "when, as here, the subject matter of the letter concerns such an important and irreversible prospect as the loss of a house." 194

Finally, this focus on safeguarding the home helps to explain the Court's recent interpretation of the federal Fair Housing Act ${ }^{195}$ in Texas Department of Housing \& Community Affairs v. Inclusive Communities Project, Inc. ${ }^{196}$ Enacted in 1968, the Act prohibits, inter alia, discrimination based on race, color, and other factors in connection with

\footnotetext{
187. Id. at 1414 (quoting Silverman v. United States, 365 U.S. 505, 511 (1961)).

188. Id. at $1414-15$.

189. 547 U.S. 220 (2006); see also Sackett v. EPA, 132 S. Ct. 1367 (2012) (holding that the Clean Water Act did not preclude pre-enforcement review of an EPA order which directed property owners, who had filled an alleged wetland in preparation for constructing a home, to restore the land to its natural condition); $c f$. Horne v. Dep't of Agric., 135 S. Ct. 2419, 2426 (2015) (using the home as the paradigm for the most protected form of property, in the sentence "[t]he Government has a categorical duty to pay just compensation when it takes your car, just as when it takes your home").

190. Flowers, 547 U.S. at 223

191. Id. at 229 (emphasis added).

192. Id. at 239

193. Id. at 229 (emphasis added). The dissenters, in contrast, complained that the "property owner's own failure to be a prudent ward of his interests" was the source of the problem. Id. at 248 (Thomas, J., dissenting). "The meaning of the Constitution," they argued, "should not turn on the antics of tax evaders and scofflaws." Id.

194. Id. at 230 (majority opinion) (emphasis added).

195. Fair Housing Act, 42 U.S.C. $\S \S 3601-3619$ (2012).

196. 135 S. Ct. 2507 (2015).
} 
the sale or rental of a home. ${ }^{197}$ Justice Kennedy's majority opinion explained that the Act was adopted against a backdrop of de facto residential segregation in many areas of the nation: "Racially restrictive covenants prevented the conveyance of property to minorities; steering by real-estate agents led potential buyers to consider homes in racially homogeneous areas; and discriminatory lending practices ... precluded minority families from purchasing homes in affluent areas." 198

The issue was whether a defendant could be held liable under the Act on a disparate-impact theory, without proof that it actually intended to discriminate. ${ }^{199}$ In other words, could a plaintiff prevail based only on a showing that the defendant's practice had a disproportionate impact on minority groups and was not justified by any legitimate rationale? ${ }^{200}$ In holding that disparate-impact claims were cognizable, the Court focused on the Act's "results-oriented language" and stressed that this outcome was consistent with its statutory purpose: to eradicate housing discrimination. ${ }^{201}$ The majority opinion closed by acknowledging the Act's "continuing role in moving the Nation toward a more integrated society." 202 By enabling more effective enforcement of the Fair Housing Act, Texas Department of Housing \& Community Affairs helps to assure that all citizens have an equal right to the home of their choice.

Indeed, the only decision where the Roberts Court ruled against a homeowner was Stop the Beach Renourishment. ${ }^{203}$ This outcome is explained by the fact that all eight participating Justices concluded that the underlying Florida Supreme Court decision under attack was correct under state law, which rendered the constitutional issues moot. ${ }^{204}$ It is also important to note that the case did not concern homes per se, but rather the location of the seaward lot line of oceanfront homes. ${ }^{205}$

\footnotetext{
197. 42 U.S.C. $\S 3604(a)$ (2012).

198. Tex. Dep't of Hous. \& Cmty. Affairs, 135 S. Ct. at 2515 (citation omitted).

199. Id. at 2513 .

200. The issue arose in an unusual factual setting. Plaintiff, a nonprofit corporation, claimed the Texas Department of Housing and Community Affairs allocated federal tax credits for lowincome housing projects in a manner that approved "too many credits for housing in predominantly black inner-city areas and too few in predominantly white suburban neighborhoods," thus perpetuating housing segregation. $I d$. at 2514 .

201. Id. at 2525 .

202. Id. at $2525-26$.

203. Stop the Beach Renourishment, Inc. v. Fla. Dep't of Envtl. Prot., 560 U.S. 702 (2010).

204. See id. at 733; id. (Kennedy, J., concurring); id. at 742 (Breyer, J., concurring).

205. See id. at 711 (plurality opinion).
} 


\section{Government Distrust}

The third distinctive theme evident in Roberts Court property jurisprudence is heightened distrust of government-a sense that officials cannot be relied upon to act in good faith in matters involving property rights. Under this mindset, federal courts must craft their decisions to safeguard owners against the serious risk that other branches of government will engage in unreasonable or even abusive conduct. As used in decisions involving state and local governments, this theme sometimes results in minimizing concerns of federalism in favor of justifying more robust federal action. ${ }^{206}$ Of course, it is often difficult to determine whether anti-government statements in Supreme Court decisions affect the outcome or are merely rhetorical flourishes. But both the frequency and the stridency of these assertions increased during the first decade of the Roberts Court. And at least in some majority and plurality opinions, the distrust of government theme is woven into the reasoning that supports the outcome. ${ }^{207}$ All eight current Justices have either written or joined in majority opinions that reflect such distrust.

Property decisions rendered during the Burger and Rehnquist eras generally did not display such distrust, except in occasional dissents. Indeed, decisions from this era reflect a certain degree of deference to government entities. In the 1978 decision in Penn Central Transportation Co. v. City of New York, for example, the Court crafted the modern three-part test for determining if a regulatory taking had occurred without expressing fear of governmental misconduct. ${ }^{208}$ One of the factors-whether the interference "arises from some public program adjusting the benefits and burdens of economic life to promote the common good"-assumed that officials would act in good faith. ${ }^{209}$ Although the Court subsequently eroded the Penn Central approach in

206. See, e.g., T-Mobile S., LLC v. City of Roswell, 135 S. Ct. 808, 815 (2015) (rejecting city's argument that interpreting federal statute to require it to state reasons for denial of cell phone tower permit "would deprive it of local zoning authority"). But the Roberts Court has sometimes employed the rhetoric of federalism in the property context. See, e.g., Nat'l Fed'n of Indep. Bus. v. Sebelius, 132 S. Ct. 2566, 2578 (2012) (quoting THE FEDERALIST No. 45, at 293 (James Madison)) (noting that " $[\mathrm{t}]$ he Framers ... ensured that powers which "in the ordinary course of affairs, concern the lives, liberties, and properties of the people' were held by governments more local and more accountable than a distant federal bureaucracy").

207. In this context, it is important to distinguish between (a) expressions of government distrust and (b) sarcasm in general. Sarcasm has certainly surfaced in Roberts Court decisions, mainly directed at other Justices; but it is used for rhetorical emphasis, not to help justify the substantive outcome.

208. See 438 U.S. 104, 124 (1978).

209. See id. 
Loretto, ${ }^{210}$ Lucas, ${ }^{211}$ Nollan, ${ }^{212}$ and Dolan, ${ }^{213}$ it did so without overtly basing their rationales on fear of governmental oppression. ${ }^{214}$ Moreover, in the 2002 decision of Tahoe-Sierra Preservation Council, Inc. v. Tahoe Regional Planning Agency, ${ }^{215}$ the Court rejected the petitioners' argument that it should adopt a per se rule for temporary takings in part because this approach would find a taking "regardless of the good faith of the planners" who adopted a moratorium, again assuming that officials would act in good faith. ${ }^{216}$ Even in Kelo v. City of New London, decided in the final year of Chief Justice Rehnquist's tenure, the plurality opinion deferred to the defendant city's decision to condemn the plaintiffs' properties, without questioning the wisdom of the decision or the good faith of city officials. ${ }^{217}$

The shift toward a more skeptical approach began in Jones $v$. Flowers, ${ }^{218}$ one of the first Roberts Court decisions involving property rights. Chief Justice Roberts' majority opinion, joined by Justices Stevens, Souter, Ginsburg, and Breyer, concluded that Arkansas violated the Due Process Clause of the Fourteenth Amendment by failing to provide a homeowner with adequate notice of a tax sale. ${ }^{219}$ The central theme in the opinion is that the state was unconcerned about the adequacy of its notice: "We do not think that a person who actually desired to inform a real property owner of an impending tax sale of a house he owns would do nothing when a certified letter sent to the owner

210. Loretto v. Teleprompter Manhattan CATV Corp., 458 U.S. 419 (1982).

211. Lucas v. S.C. Coastal Council, 505 U.S. 1003 (1992). Justice Scalia certainly touched on the government mistrust theme in his majority opinion in Lucas when he noted that a regulation which required land to be substantially left in its natural state carried the risk that it was "being pressed into some form of public service under the guise of mitigating serious public harm." Id. at 1018.

212. Nollan v. Cal. Coastal Comm'n, 483 U.S. 825 (1987).

213. Dolan v. City of Tigard, 512 U.S. 374 (1994).

214. The Court justified the results in Loretto and Lucas, for example, by reference to supposed traditional rules rather than on fear of government misconduct. Loretto, 458 U.S. at 435 ("historical rule"); Lucas, 505 U.S. at 1016 ("[a]s we have said on numerous occasions"). Nollan was also based on an even-handed assessment, aside from an ideological flourish by Justice Scalia, who noted that an improper permit condition would be "not a valid regulation of land use but 'an out-and-out plan of extortion."” 483 U.S. at 837 (quoting J.E.D. Assocs., Inc. v. Atkinson, 432 A.2d 12, 14 (N.H. 1981), overruled by Town of Auburn v. McEvoy, 553 A.2d 317 (N.H. 1988)). Scalia quoted this same language in Dolan. 512 U.S. at 387 (quoting J.E.D. Assocs., 432 A.2d at 14-15).

215. 535 U.S. $302(2002)$.

216. Id. at 337-38.

217. 545 U.S. 469, 480-84 (2005).

218. 547 U.S. 220 (2006).

219. Id. at 239 . 
is returned unclaimed." 220 And in the closing paragraph of the opinion, Roberts complained:

There is no reason to suppose that the State will ever be less than fully zealous in its efforts to secure the tax revenue it needs. The same cannot be said for the State's efforts to ensure that its citizens receive proper notice before the State takes action against them. ${ }^{221}$

The implication here is that officials are predominantly concerned with enriching the state rather than protecting the rights of its citizens.

One year later, in Rapanos v. United States, the plurality opinion written by Justice Scalia struck a similar note, this time directed against regulations issued by the U.S. Army Corps of Engineers. ${ }^{222}$ The issue in the case was the appropriate interpretation of the phrase "waters of the United States" under the provisions of the Clean Water Act which regulate the filling of wetlands. ${ }^{223}$ Scalia complained about an "immense expansion of federal regulation of land use that has occurred under the Clean Water Act-without any change in the governing statute-during the past five Presidential administrations."224 The Army Corps of Engineers, he asserted, "exercises the discretion of an enlightened despot" in deciding whether to issue a permit to fill wetlands. ${ }^{225}$ Concurring in the decision, Chief Justice Roberts lamented that rather than narrowing its authority over wetlands in response to prior Supreme Court decisions, "the Corps chose to adhere to its essentially boundless view of the scope of its power." 226

Yet later that same year, in Wilkie v. Robbins, ${ }^{227}$ the Court resisted temptation to rule against the federal government where its agents allegedly engaged in a campaign of "harassment and intimidation" to force a landowner to convey an easement over his land to the Bureau of

\footnotetext{
220. Id. at 229 .

221. Id. at 239 .

222. 547 U.S. 715 (2006)

223. Id. at 729 .

224. Id. at 722 .

225. Id. at 721. Scalia also rejected the argument that Congress had acquiesced in the challenged regulations, noting that the Court could not determine whether the failure of Congress to act was attributable to its members' belief that the regulations were appropriate, their assumption that the courts would correct any problems, "or indeed simply to their unwillingness to confront the environmental lobby." Id. at 750 .

226. Id. at 758 (Roberts, J., concurring); see also T-Mobile S., LLC v. City of Roswell, $135 \mathrm{~S}$. Ct. 808, 815 (2015) (disregarding the city's argument that the Court's interpretation of federal statute would "deprive it of local zoning authority").

227. 551 U.S. 537 (2007).
} 
Land Management, by declining to recognize a new Bivens action. ${ }^{228}$ Indeed, Justice Souter's majority decision opined that even if "[t]he action claimed to be retaliatory may gratify malice in the heart of the official who takes it... the official act remains an instance of hard bargaining intended to induce the plaintiff to come to legitimate terms." "229 Dissenting, Justices Ginsburg and Stevens protested that " $[t]$ he constitutional guarantee of just compensation would be worthless if federal agents were permitted to harass and punish landowners who refuse to give up property without it.",230

The Court returned to the distrust theme in its 2010 plurality opinion in Stop the Beach Renourishment, Inc. v. Florida Department of Environmental Protection, this time focused on state court judges. ${ }^{231}$ As noted above, Justice Scalia's opinion asserted the novel claim that the Takings Clause encompassed the taking of property by judicial decisions. ${ }^{232}$ "It would be absurd," he asserted, "to allow a State to do by judicial decree what the Takings Clause forbids it to do by legislative fiat." ${ }^{233}$ In order to determine whether a state judicial decision has "taken" a property right, he reasoned that federal courts must necessarily be the final arbiter of what property rights exist under state law: "A constitutional provision that forbids the uncompensated taking of property is quite simply insusceptible of enforcement by federal courts unless they have the power to decide what property rights exist under state law." ${ }^{234}$ Inherent in this view is the notion that state court judges cannot be trusted to determine state law. As Scalia commented: "[O]ur opinion does not trust judges with the relatively small power Justice Kennedy now objects to. It is we who propose setting aside judicial decisions that take private property ...."235

A similar, if muted, theme can be seen in the 2012 decision of Arkansas Game \& Fish Commission v. United States, where Justice Ginsburg's unanimous opinion identified the factors to be considered in determining whether a temporary physical invasion of private property

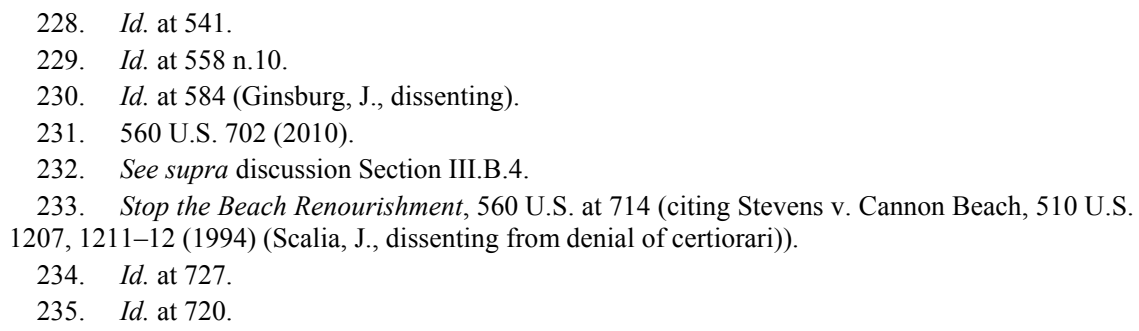


by government should be deemed a compensable taking. ${ }^{236}$ The list included a factor concerning the intentionality of government conduct: "the degree to which the invasion is intended or is the foreseeable result of authorized government action."237 This factor-which implies potential bad faith by government officials-had not previously surfaced in the Court's modern takings jurisprudence.

Justice Alito struck the same anti-government cord in Sackett v. EPA in $2012 .^{238}$ He concurred in the majority opinion that property owners were entitled to challenge administrative compliance orders issued under the Clean Water Act, beginning his opinion with this sentence: "The position taken in this case by the Federal Government-a position that the Court now squarely rejects-would have put the property rights of ordinary Americans entirely at the mercy of Environmental Protection Agency (EPA) employees." ${ }^{239}$ He continued: "[T]he combination of the uncertain reach of the Clean Water Act and the draconian penalties imposed for the sort of violations alleged in this case still leaves most property owners with little practical alternative but to dance to the EPA's tune." ${ }^{240}$ The clear implication of these remarks is that EPA officials cannot be trusted.

In the 2013 decision of Koontz v. St. Johns River Water Management District, where the Court extended the Nollan-Dolan rule, Justice Alito centered his majority opinion on fear of government misconduct. ${ }^{241} \mathrm{He}$ began by characterizing Nollan and Dolan as providing protection against "the misuse of the power of land-use regulation." 242 Land use applicants, he reasoned, were especially vulnerable to "coercion" and "[e]xtortionate demands" by local officials. ${ }^{243}$ "Extortionate demands for property in the land-use permitting context," he explained, "run afoul of the Takings Clause ... because they impermissibly burden the right not to have property taken without just compensation."244 Turning to the monetary exactions issue, Alito asserted that the Nollan-Dolan test had to be expanded to encompass demands for fees because otherwise "it would be very easy for land-use permitting officials to evade the

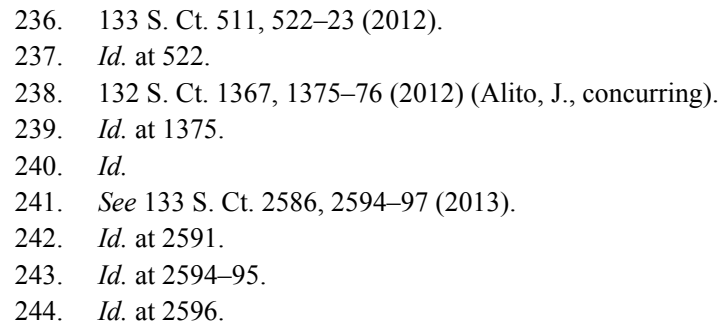


limitations" of these decisions. ${ }^{245}$ The common themes running through these justifications is that local officials are likely to both (a) make extortionate demands on land developers and (b) seek to evade Supreme Court rulings.

An echo of the government mistrust theme can also be seen in the 2015 decision of Horne v. Department of Agriculture, where eight Justices agreed that the Takings Clause applied equally to real property and personal property. ${ }^{246}$ As discussed above, the case involved a federal program intended to aid growers by stabilizing the price for raisins by keeping part of the crop off the market-a program that most growers supported. $^{247}$ Yet Chief Justice Roberts' majority opinion summarized the Court's holding in this manner: "The Government has a categorical duty to pay just compensation when it takes your car, just as when it takes your home."248 The direct address to the reader ("your") and substitution of a personally-owned item ("car") for tons of raisins destined for commercial sale makes the holding more memorable. Yet it virtually warns the reader against a supposed danger that the government might try to seize his property without any payment. ${ }^{249}$

Admittedly, it can be difficult to distinguish rhetoric from reasoning in Supreme Court opinions. But, at a minimum, the rationales in certain Roberts Court decisions in property-related cases appear to be partially premised on judicial fear of misconduct by other branches of government, ranging from federal officials to local legislatures to state courts. Taken to its logical extreme, the implication of this view is that only federal courts may be relied upon to safeguard property rights. Perhaps Justice Scalia reflected this mindset in his Stop the Beach Renourishment plurality opinion when he proclaimed: "Where the power of this Court is concerned, one must never say never." 250

\footnotetext{
245. Id. at 2599 .

246. 135 S. Ct. 2419, 2423, 2425-28 (2015).

247. See supra discussion Section III.B.4.

248. Horne, 135 S. Ct. at 2426 (emphasis added).

249. See also Florida v. Jardines, 133 S. Ct. 1409, 1414 (2013) (quoting Silverman v. United States, 365 U.S. 505, 511 (1961)) (noting that the core of the Fourth Amendment was "the right of a man to retreat into his own home and there be free from unreasonable government intrusion").

250. Stop the Beach Renourishment, Inc. v. Fla. Dep't of Envtl. Prot., 560 U.S. 702, 725 (2010).
} 


\section{E. "Property" Boundaries}

\section{Expanding Boundaries}

The central question in American property law is simply stated: What is "property"? The word is notoriously difficult to define. Indeed, one scholar claims that "[t]he question is unanswerable."251

The Roberts Court continues to use the traditional metaphor that "property" may be viewed as a "bundle of rights," following in the footsteps of prior Courts. Two decisions from the 2014 term illustrate the point. In Henderson v. United States, ${ }^{252}$ the Court unanimously held that a federal statute that made it unlawful for a convicted felon to "possess" a firearm did not eliminate the other "proverbial sticks in the bundle of property rights." ${ }^{253}$ Thus, the government was not entitled to prevent Henderson, a convicted felon, from exercising "the right merely to sell or otherwise dispose of that item."254 A few weeks later, in Horne v. Department of Agriculture, ${ }^{255}$ the Court found that the federal government had violated the Takings Clause because a government program eliminated 'the entire 'bundle' of property rights in the appropriated raisins - 'the rights to possess, use and dispose of' them." But while the bundle of rights metaphor may be useful in deconstructing the components of "property," it provides no real guidance about what "property" is in the first instance.

The scope of laws that regulate property is inextricably intertwined with the meaning of "property." For example, the Takings Clause and the Due Process Clause of the Fifth Amendment provide different forms of protection for "property." A court might enlarge the reach of the Takings Clause either by broadening the meaning of the term "taken" or the meaning of "property." In like fashion, the breadth of the Due Process Clause is determined by the meaning of both "due process" and "property." The same duality is evident in interpreting statutes and case

251. John Edward Cribbit, Concepts in Transition: The Search for a New Definition of Property, 1986 U. ILL. L. REV. 1, 1.

252. 135 S. Ct. $1780(2015)$

253. Id. at 1784 .

254. Id. at 1785; cf. Watson v. United States, 552 U.S. 74, 76 (2007) (holding that a person who trades drugs for a gun is not "using" a firearm "during ... [a] drug trafficking crime").

255. 135 S. Ct. 2419 (2015).

256. Id. at 2428 (quoting Loretto v. Teleprompter Manhattan CATV Corp., 458 U.S. 419, 435 (1982)); see also Permanent Mission of India to the United Nations v. City of New York, 551 U.S. 193, 198 (2007) (noting that "the right to convey" is "one of the quintessential rights of property ownership"). 
law involving "property."

The Roberts Court is directly enlarging the substantive protection for property, as discussed earlier in this Article. But there are also indications that the Court, or at least part of the Court, may be seeking to do the same thing indirectly - by enlarging the boundaries of what "property" means. ${ }^{257}$ Tentative efforts on this front can be identified in three areas. First, is everything that has value "property"? Second, should real property and personal property be given equal legal protection as "property"? Finally, is the meaning of "property" protected by the Takings Clause and the Due Process Clause static or dynamic?

\section{2. "Property" and Value}

Courts and scholars have struggled for decades to define the meaning of "property" as the term is used both in the Constitution and in federal statutes. It has been traditionally accepted that states have the principal role in defining the meaning of "property" as a general matter, ${ }^{258}$ and that federal courts will thus largely rely on state law to define the term. For example, in Board of Regents of State Colleges v. Roth, a Burger era decision, the Court explained that the creation and scope of property interests were "defined by existing rules or understandings that stem from an independent source such as state law."

Yet this approach creates the risk of circularity, as Justice Kennedy explained in two Rehnquist Court decisions. In his Lucas concurrence, Kennedy noted that if "the owner's reasonable expectations are shaped by what courts allow as a proper exercise of governmental authority, property tends to become what courts say it is."260 Kennedy's solution to the circularity dilemma was to broaden the scope of owner expectations: "The expectations protected by the Constitution are based on objective rules and customs that can be understood as reasonable by all parties involved ... in light of the whole of our legal tradition." ${ }^{261} \mathrm{He}$ expanded

257. Cf. Ark. Dep't of Health \& Human Servs. v. Ahlborn, 547 U.S. 268, $285-86$ (2006) (rejecting state's assertion that settlement proceeds were not "property" owned by the plaintiff).

258. Stop the Beach Renourishment, Inc. v. Fla. Dep't of Envtl. Prot., 560 U.S. 702, 707 (2010) (citing Phillips v. Wash. Legal Found., 524 U.S. 156, 164 (1998)) (“Generally speaking, state law defines property interests ...."); see also Giles v. California, 554 U.S. 353, 375 (2008) (observing that a proposition "of which we have no doubt" is that "States may allocate property rights as they see fit"); Travelers Cas. \& Sur. Co. v. Pac. Gas \& Elec., 549 U.S. 443, 451 (2007) (quoting Butner v. United States, 440 U.S. 48, 55 (1979)) ("[P]roperty interests are created and defined by state law").

259. 408 U.S. 564, 577 (1972).

260. Lucas v. S.C. Coastal Council, 505 U.S. 1003, 1034 (1992) (Kennedy, J., concurring).

261. Id. at 1035 . 
on this theme in his plurality opinion in Palazzolo $v$. Rhode Island, ${ }^{262}$ describing property as stemming from the "common, shared understandings . . . derived from a State's legal tradition." "263

At bottom, these authorities seek to provide a process for determining what constitutes "property" based on the facts of a particular case, rather than providing a general definition. This is far from a workable standard. Indeed, Kennedy has acknowledged that the Court needs to develop a "neutral, stable, extrinsic" definition of property. ${ }^{264}$

The Roberts Court addressed a key issue in this definitional struggle in Sekhar v. United States: is everything that may indirectly have value "property"? ${ }^{265}$ The case arose against a backdrop of earlier decisions which held that not all valuable interests constituted "property." For example, in the 1945 case of United States v. Willow River Power Co., the Court observed that "not all economic interests are 'property rights'; only those economic advantages are 'rights' which have the law back of them."266 And during the final year of the Rehnquist era, the Court observed in Town of Castle Rock v. Gonzales that an interest was not "property" under the Fourteenth Amendment if it had no "ascertainable monetary value."267 But Sekhar appears to contradict the Court's prior holdings. ${ }^{268}$

Sekhar involved a vague and intangible "right" located on the fuzzy border between property and non-property: an employee's right to make a recommendation to his superior. ${ }^{269}$ The case required the Court to interpret the Hobbs Act, which imposes criminal liability for extortion related to interstate commerce ${ }^{270}$ the Act defines "extortion" to include "obtaining of property from another, with his consent, induced by

262. 533 U.S. 606 (2001).

263. Id. at 630 (citing Lucas, 505 U.S. at 1029-30).

264. Videotape: Archie Hefner Memorial Lecture-Property and Our Constitutional Tradition: Some Hobbesian Sticks in the Lockean Bundle (Anthony M. Kennedy 1991) (on file with the Gordon D. Schaber Law Library, University of the Pacific, McGeorge School of Law).

265. See 133 S. Ct. 2720, 2726 (2013).

266. 324 U.S. 499, 502 (1945).

267. 545 U.S. 748, 766 (2005) (quoting Thomas W. Merrill, The Landscape of Constitutional Property, 86 VA. L. REV. 885, 964 (2000)).

268. It is certainly possible that the definitions of the term "property" as used in the Fifth and Fourteenth Amendments might differ among themselves, and also deviate from various statutory definitions of the term. Conceding this arguendo, nothing in the Hobbs Act suggests that it uses the term "property" in an unusual sense, and the Sekhar approach varies wildly from what must be viewed as the core meaning of the term, whatever variance there may be on the margins.

269. Sekhar, 133 S. Ct. at 2723.

270. Id.; 18 U.S.C. $§ 1951$ (2012). 
wrongful use of actual or threatened force, violence, or fear." ${ }^{271}$ The issue was whether using threats "to compel a person to recommend that his employer approve an investment" was obtaining "property" from another. $^{272}$ The Second Circuit held that the employee, the general counsel of a state agency, "had a property right ... to recommend-free from threats-whether the [agency] should" invest in a fund managed by a particular private firm. ${ }^{273}$ It accordingly upheld the defendant's conviction. $^{274}$

The Supreme Court reversed in a unanimous decision, but with differing rationales that went beyond the statutory meaning of "property" under the Act. ${ }^{275}$ Chief Justice Roberts and Justices Thomas, Ginsburg, Breyer, and Kagan joined Justice Scalia's majority opinion. ${ }^{276}$ Scalia initially refused to decide whether the right to make such a recommendation was " "property' in a broad sense or not"; but he reasoned that even if it were, it was not property that could be transferred to another-and thus not "obtainable property under the Hobbs Act."277

Justice Alito, joined by Justices Kennedy and Sotomayor, concurred in the result. ${ }^{278}$ Alito noted that dicta in earlier decisions suggested that property covered by the Act extended to "any valuable right considered as a source or element of wealth," also endorsed this broad definition of the term. ${ }^{280}$ But, concluding that "the jury's verdict stretches the concept of property beyond the breaking point," Alito reasoned that the right to make such a recommendation was not "property" even if it might have some value. ${ }^{281}$ He noted that "[d] espite the breadth of some of these formulations," the term "plainly does not reach everything that a person may hold dear; nor does it extend to everything that might in some indirect way portend the possibility of future economic gain." ${ }^{282}$ Alito based his analysis on the reasonable expectations approach, noting that "[i]t is not customary to refer to an

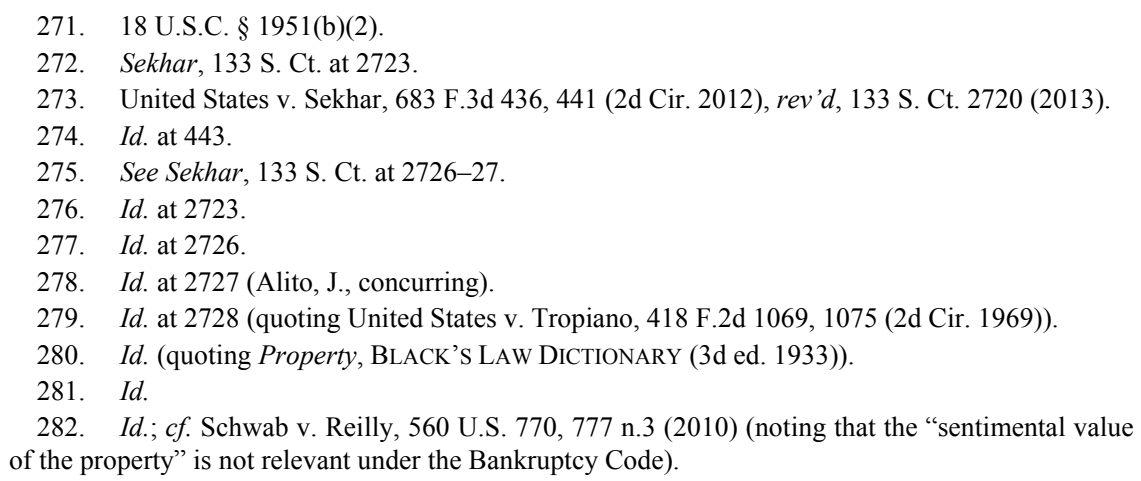


internal recommendation to make a government decision as a form of property" and that "[i]t would seem strange to say that the government or its employees have a property interest in their internal recommendations." 283

Justice Scalia responded to Alito's analysis in a footnote, indicating that he was "not sure" whether the right was "property"; but he seemed to suggest that any valuable item might be property: "If one defines property to include anything of value, surely some rights to make recommendations would qualify - for example, a member of the Pulitzer Prize Committee's right to recommend the recipient of the prize." 284 Scalia went on to observe that "a prominent journalist would not give up that right (he cannot, of course, transfer it) for a significant sum of money-so it must be valuable." 285

Thus, five current Justices appear to agree that a right has "value"-and thus constitutes "property"-if a person would not surrender it in return for a monetary payment, even if (a) the right is not transferable in the market sense and (b) it has no ascertainable monetary value. But there is a plethora of "rights" in everyday life which a person could conceivably give up in return for an undetermined amount of money. This list might include the "rights" to apply for a job, eat meat, enjoy art, drive a car, read a book, or look at a starry sky. None of these "rights" have market value; nor are any transferable. Yet under the majority approach, they are all arguably "property." This position would dramatically enlarge what the law has traditionally viewed as "property," thereby expanding the protection that "owners" receive.

\section{Real Property v. Personal Property}

Another ongoing debate is whether real property is entitled to greater protection than personal property. Rehnquist era opinions reflected such a distinction, for example, in the context of the Takings Clause. In Andrus v. Allard (1979), the Court held that a law prohibiting owners from selling their eagle feathers was not a taking; ${ }^{286}$ but in Hodel $v$. Irving (1987) it held that a law prohibiting Native Americans from devising their lands was a taking. ${ }^{287}$ Justice Scalia reflected on this

\footnotetext{
283. Sekhar, 133 S. Ct. at 2728 (Alito, J., concurring).

284. Id. at 2726 n.5 (majority opinion).

285. Id.

286. 444 U.S. $51,67-68(1979)$

287. 481 U.S. $704,716-18$ (1987).
} 
distinction in his majority opinion in Lucas v. South Carolina Coastal Council:

[I]n the case of personal property, by reason of the State's traditionally high degree of control over commercial dealings, [an owner] ought to be aware of the possibility that new regulation might even render his property economically worthless (at least if the property's only economically productive use is sale or manufacture for sale). In the case of land, however, we think the notion pressed by the Council that title is somehow held subject to the "implied limitation" that the State may subsequently eliminate all economically valuable use is inconsistent with the historical compact recorded in the Takings Clause.... ${ }^{288}$

The clear implication is that a regulation which eliminates all economic value of real property is a taking; but a regulation which has the same impact on personal property is not. Thus, the jurisprudence of the Rehnquist Court suggested that government probably has greater leeway in regulating personal property than real property. The Roberts Court rejects this view. More than any of its predecessors, the Roberts Court has moved toward extending equal protection to both forms of property. ${ }^{289}$

The Roberts Court took the first steps toward eliminating any distinction between real property and personal property under the Takings Clause. Writing for the five-member majority in Koontz v. St. John's River Water Management District, ${ }^{290}$ Justice Alito extended the Nollan-Dolan approach from exactions of real property to encompass demands for monetary payments. ${ }^{291}$ Alito justified this shift on practical grounds, noting that such fees are "functionally equivalent to other types of land use exactions," that is, to government demands for exactions of real property. ${ }^{292}$ Seemingly, then, the Nollan-Dolan rule now applies equally to exactions of real property and money-and thus presumably to any other form of personal property as well. ${ }^{293}$

288. 505 U.S. 1003, 1027-28 (1992) (citation omitted) (citing Andrus, 444 U.S. at 66-67).

289. The Court also seemed to equate the two categories in McBurney v. Young, where it explained that the right to "'property, either real or personal,' has long been seen as one of the privileges of citizenship.” 133 S. Ct. 1709, 1716 (2013) (quoting Corfield v. Coryell, 6 F. Cas. 546, 552 (C.C.E.D. Pa. 1823)).

290. 133 S. Ct. 2586 (2013).

291. See supra discussion Section III.B.4.

292. Koontz, 133 S. Ct. at 2599.

293. Cf. Robers v. United States, 134 S. Ct. 1854, 1857-58 (2014) (concluding that the statutory restitution obligation for loan fraud was reduced only by the proceeds received from the sale of the collateral, not the value of the collateral itself, because the "property" at issue was money, 
Two years later, the Court examined the issue more broadly in Horne v. Department of Agriculture. ${ }^{294}$ In the underlying decision, the Ninth Circuit refused to find a taking of the Hornes' raisins under Loretto, in part based on the rationale that "the Takings Clause affords less protection to personal than to real property." 295 It based this conclusion mainly on the excerpt from Justice Scalia's majority opinion in Lucas quoted above. ${ }^{296}$ Writing for the Court, Chief Justice Roberts soundly rejected this distinction in the context of a physical taking:

Nothing in the text or history of the Takings Clause, or our precedents, suggests that the rule [governing takings] is any different when it comes to appropriation of personal property. The Government has a categorical duty to pay just compensation when it takes your car, just as when it takes your home.

The Court explained away the Lucas dictum on the basis that that case "was about regulatory takings, not direct appropriations." 298 Notably, Justices Scalia, Kennedy, Thomas, Alito, Ginsburg, Breyer, and Kagan all joined in this part of the opinion. ${ }^{299}$ After Horne, it is clear that seven current Justices believe that Loretto applies equally to physical takings of real property and personal property.

In the wake of Koontz and Horne, it is increasingly likely that a future Court will narrow the distinction between real property and personal property under the Takings Clause in the context of regulatory takings. Under the logic followed by the Horne Court, certainly nothing in the text of the Clause justifies any distinction between the two. Yet because commentators generally agree that the Framers did not contemplate that the Clause would apply to regulations that merely restrict the use of property, ${ }^{300}$ such textual analysis provides little assistance. The central difficulty is that the Framers clearly intended state and federal governments to exercise broad control over intrastate

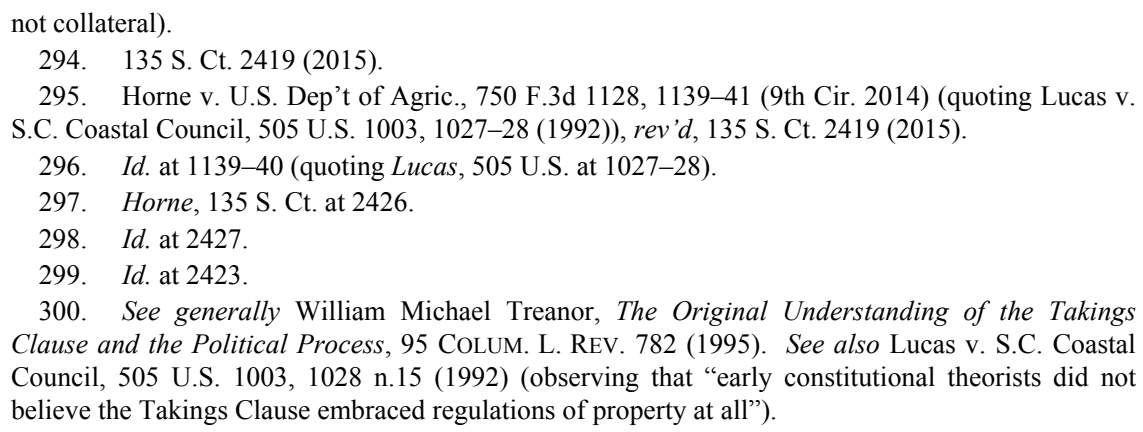


and interstate commerce-which would necessarily include restrictions on the manufacture, sale, and possession of personal property.

Riley v. California, ${ }^{301}$ a recent Fourth Amendment decision, may signal that the Roberts Court is also beginning to close the gap between real property and personal property in other contexts. ${ }^{302}$ On its face, the Amendment expressly extends to searches and seizures of both certain real property ("houses") and personal property ("papers, and effects"). ${ }^{303}$ Yet the Court has often given less protection to personal property which is seized or searched outside of the home.

When Riley was searched incident to a traffic stop for expired registration tags, officers seized his cell phone, examined its contents, and found incriminating photos and videos. ${ }^{304}$ This evidence was admitted at trial over Riley's objection that the officers had conducted a warrantless search. ${ }^{305}$ Writing for the eight-member majority, Chief Justice Roberts reasoned that the search was improper. ${ }^{306}$ Although it was well-settled that officers could search an arrestee without a warrant, Roberts explained that a cell phone was fundamentally different from physical objects typically found in such a search, such as keys or cigarettes. ${ }^{307}$ Because a cell phone has immense data storage capacity, he reasoned, its search poses a significant threat to personal privacy-much like the search of a home: "Indeed, a cell phone search would typically expose to the government far more than the most exhaustive search of a house...."308 Thus, seven current Justices apparently agree that computers, tablets, and other digital media interfaces will receive heightened protection under the Fourth Amendment-akin to the protection accorded to the family home-despite their traditional classification as personal property.

\section{Static Property v. Dynamic Property}

Is the definition of "property" as used in the Due Process Clause and Takings Clause static or dynamic? The Supreme Court has addressed

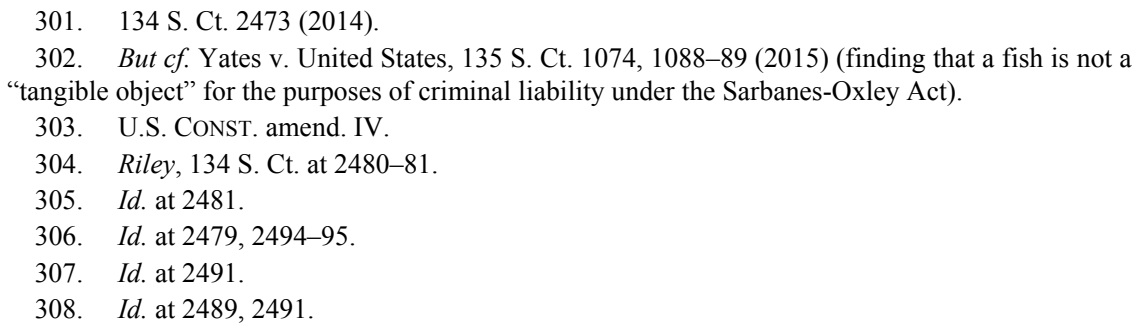


this issue to some extent in the past. But the debate between Justices Scalia and Kennedy in Stop the Beach Renourishment ${ }^{309}$ may provide new insight into how the Court will approach the issue in the future-with implications for how far the Constitution protects property rights.

The foundation of the American property law system is English law as it existed before 1776. As Morton Horwitz has observed, the English system was rooted in a "static agrarian conception" of property law ${ }^{310}$-and accordingly, a static view of what constituted "property." 311 Yet a body of American property law began to arise in the nineteenth century as judges altered English doctrines to meet conditions in the United States, which were quite different from those in England. As American courts retooled English property law doctrines in order to encourage the development of wilderness lands, mainly for agricultural use, the meaning of "property" evolved over time. ${ }^{312}$

The American wilderness had largely disappeared by the dawn of the twentieth century, but population growth and urbanization created new pressures on property law. In this setting, the Court again acknowledged that the permissible scope of property law-and thus the definition of "property" itself-must evolve in response to changing conditions. The foundation of modern land use regulation is the 1926 decision in Village of Euclid v. Ambler Realty Co., where the Court upheld the constitutionality of comprehensive zoning against due process and equal protection attacks. ${ }^{313}$ It noted that the increasing urbanization and population growth of the era justified "additional restrictions in respect of the use and occupation of private lands in urban communities...

309. Stop the Beach Renourishment, Inc. v. Fla. Dep't of Envtl. Prot., 560 U.S. 702 (2010).

310. Morton J. Horwitz, The Transformation of AMERICAN LAw, 1780-1860, at 31 (1977).

311. See generally John G. Sprankling, The Antiwilderness Bias in American Property Law, 63 U. CHI. L. REV. 519 (1996). England was a mature agrarian economy, where most of the land surface was already in productive use, primarily as crop land and permanent pasture. But the United States was essentially a wilderness nation, largely in the same primeval state which existed before European colonization. As Justice Story explained in an early Supreme Court decision, "[t]he country was a wilderness, and the universal policy was to procure its cultivation and improvement." Van Ness v. Pacard, 27 U.S. 137, 145 (1829).

312. See Elizabeth G. Patterson, Property Rights in the Balance-The Burger Court and Constitutional Property, 43 MD. L. REV. 518, 518 (1984) ("The concept of property is not static . . . Because circumstances have changed significantly since the colonial era, to the modern layman or lawyer the concept of property differs from that intended by the colonial farmers and merchants who drafted and ratified the Constitution.").

313. 272 U.S. 365, 397 (1926); see also Pa. Coal Co. v. Mahon, 260 U.S. 393, 413 (1922) (noting that "some values are enjoyed under an implied limitation and must yield to the police power"). 
[that] a century ago, or even half a century ago, probably would have been rejected as arbitrary and oppressive." ${ }^{314}$ Accordingly, it reasoned that the scope of the application of constitutional guarantees concerning property must "expand or contract to meet the new and different conditions which are constantly coming within the field of their operation. In a changing world it is impossible that it should be otherwise." 315

In recent decades, the static-dynamic dispute has largely been framed in terms of whether a compensable taking has occurred under the Fifth Amendment. Under the Takings Clause "property" may not be "taken" by the federal government for "public use" unless just compensation is provided to the owner. ${ }^{316}$ By necessity, there is a close relationship between the definition of "property" and the standard for determining when property is "taken." Although the Court has focused on defining property in terms of the reasonable expectations of the owner, it has not clearly decided whether such expectations might change over time.

The static-dynamic fissure surfaced during the Rehnquist era in Lucas v. South Carolina Coastal Council, ${ }^{317}$ as evidenced by the contrast between Justice Scalia's majority opinion and Justice Kennedy's concurrence. Scalia seemed to concede that the definition of property might change over time to some extent-without giving rise to takings liability - when he noted that "[i]t seems to us that the property owner necessarily expects the uses of his property to be restricted, from time to time, by various measures newly enacted by the State in legitimate exercise of its police powers." 318 But he stressed the limited scope of this approach: when a regulation prohibited "all economically beneficial use of land" it would constitute a taking unless it was justified by "background principles [that]... the State's law of property and nuisance already place upon land ownership." ${ }^{\text {319 }}$ This reference to "background principles" implied a static set of property doctrines. Justice Kennedy's concurrence took a broader approach, stressing that an owner's "reasonable expectations" should be "understood in light of the whole of our legal tradition," which envisioned gradual changes in property rights over time. ${ }^{320}$ Thus, "[t]he State should not be prevented

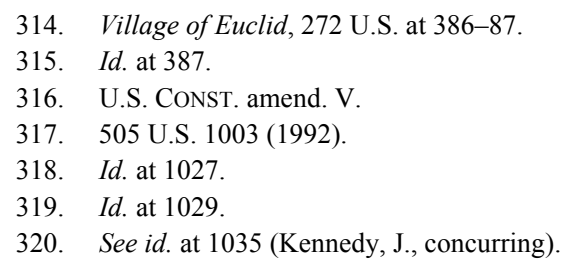


from enacting new regulatory initiatives in response to changing conditions .... The Takings Clause does not require a static body of state property law." ${ }^{321}$ Dissenting, Justice Stevens complained that the majority approach "effectively freezes the State's common law, denying the legislature much of its traditional power to revise the law governing the rights and uses of property.",322

In the Roberts Court, the static-dynamic dispute has widened from a fissure into a chasm. In Stop the Beach Renourishment, Chief Justice Roberts and Justices Thomas and Alito joined Justice Scalia's plurality opinion, which announced that if a court "declares that what was once an established right of private property no longer exists, it has taken that property." 323 Under this logic, property law is forever frozen in time regardless of any changed circumstances that might justify modification. This is an avowedly originalist view of property rights, which echoes the approach of the Roberts Court in its Second and Fourth Amendment jurisprudence-examining the scope of the respective rights to possess guns and be free from home searches, as defined by eighteenth-century law.

Concurring in the result and joined by Justice Sotomayor, Justice Kennedy noted that "[s]tate courts generally operate under a commonlaw tradition that allows for incremental modifications to property law." 324 Because "owners may reasonably expect or anticipate courts to make certain changes in property law," he reasoned, an "incremental modification" by government action would not violate the Constitution. ${ }^{325}$ In other words, the scope of property rights may change over time to some extent as the expectations of property owners evolve. Kennedy cited the example of the traditional common law rule governing liability when roots from a tree located on one owner's property damage an adjacent property: "If a court deems that, in light of increasing urbanization, the former rule for allocation of these costs should be changed, thus shifting the rights of the owners, it may well increase the value of one property and decrease the value of the other." ${ }^{326}$ But under Kennedy's approach, this would probably be consistent with the Constitution.

\footnotetext{
321. Id.

322. Id. at 1068-69 (Stevens, J., dissenting).

323. Stop the Beach Renourishment, Inc. v. Fla. Dep't of Envtl. Prot., 560 U.S. 702, 715 (2010).

324. Id. at 736 (Kennedy, J., concurring).

325. Id. at 738 .

326. Id.
} 
In turn, Scalia insisted that the definition of "property" was static. He asserted that Kennedy's above analysis was "an astounding statement." " " $\mathrm{I}] \mathrm{t}$ is not true," he asserted, that the "common-law tradition ... allows for incremental modifications to property law,' so that 'owners may reasonably expect or anticipate courts to make certain changes in property law." ",328 This position went well beyond the position he and others had supported in Lucas, where he appeared to concede that property rights could be modified by government action, at least to some extent, without incurring liability for a taking. ${ }^{329}$

The historical record overwhelmingly supports the Kennedy position. American courts have routinely modified the common law rights of property owners for centuries in response to changing conditions-without any serious argument that this violated the Constitution. While there are many examples, one illustration suffices to make the point. Consider the easement by necessity. Suppose that A, who has title to a large tract of land that adjoins a public road, conveys part of the land to B. Under the traditional view, B is entitled to an easement by necessity over A's retained land to reach the road only if B can establish strict necessity, that is, if B had no legal right of access to a public road when A severed title. Under the Scalia approach, one might argue that A has an "established right of private property" to avoid imposition of an easement by necessity over his land unless strict necessity exists. But over time, changing conditions have led most American courts to reject the strict necessity standard in favor of the reasonable necessity approach. $\mathrm{B}$, the party seeking the easement, need only show that it is beneficial or convenient to her land. This arguably "eliminates" the right of landowners like A to avoid such easements. Scalia presumably would have argued that this is a compensable taking-though no landowner has ever made such a claim. In turn, Kennedy would probably find no taking on the basis that the reasonable expectations of landowners evolve over time.

\footnotetext{
327. Id. at 722 (plurality opinion).

328. Id. (citations omitted) (quoting $i d$. at 736, 738 (Kennedy, J., concurring)).

329. Lucas v. S.C. Coastal Council, 505 U.S. 1003, 1027-28 (1992). Scalia's position here seems to be inconsistent with his dissent in Georgia v. Randolph, 547 U.S. 103 (2006), where the issue was whether a wife could authorize a search of her husband's house. Id. at 106 . He noted that "[n]o one supposes that the meaning of the Constitution changes as States expand and contract property rights." Id. at 144 (Scalia, J., dissenting). Thus, even if a wife could not authorize such a search in 1791, when the Bill of Rights was ratified, "the fact that current property law provides otherwise is ... [not] troublesome for the originalist." Id. These statements appear to concede that a husband's historic right to exclude could be restricted by state law which would, in turn, narrow the scope of the husband's Fourth Amendment protection.
} 
In short, a static definition of "property" is inconsistent with the American legal tradition. Decisions of American courts routinely alter, restrict, or even eliminate property rights over time, consistent with the common law tradition, as they gradually respond to changing economic, social, geographical, and technological conditions. Absent unusual circumstances, a property owner cannot hold a "legitimate expectation" that her property rights will never be impaired by government action-and thus Kennedy would argue that no compensation is due.

In summary, three current Justices (Roberts, Thomas, and Alito) endorse the static approach to the definition of "property" as embodied in the Stop the Beach Renourishment plurality opinion; two Justices (Kennedy and Sotomayor) disagree; and the remaining three Justices (Ginsburg, Breyer, and Kagan) have not yet taken a position on the issue. Taken to its logical extreme the static approach would require either that (a) courts refrain from deciding cases in a manner that might modify property law or (b) the government compensate owners for such changes. Neither outcome is palatable. The first alternative abandons our common law tradition. And the second invokes Justice Holmes' warning in Pennsylvania Coal Co. v. Mahon that "[g]overnment hardly could go on if to some extent values incident to property could not be diminished without paying for every such change in the general law." 330

\section{The PATH AHEAD: Property JURISPRUdENCE IN THE POST-SCALIA ERA}

Justice Scalia was an outspoken champion of property rights who profoundly influenced the jurisprudence of the Rehnquist and Roberts Courts during his thirty-year tenure. But his passing is unlikely to signal a major change in the Court's approach to property issues. The most profound effect of his absence will be to slow the pace at which the Court's property jurisprudence expands.

One prediction is relatively easy: the Roberts Court will not reverse any of its core decisions interpreting the scope of protection for constitutional property under the Second, Fourth, Fifth, and Fourteenth Amendments. The Court traditionally applies stare decisis with more stringency in cases involving property rights than in most other types of cases, because of the belief that owners are likely to change their positions in reliance on these holdings. All the current members of the Court have embraced various formulations of this precept. In the 2015 
decision of Kimble v. Marvel Entertainment, $L L C$, for example, five current Justices-joined by Scalia-endorsed the statement in Justice Kagan's majority opinion that because property rights were entitled to a "superpowered form of stare decisis, we would need a superspecial justification" to overrule a decision in this area. ${ }^{331}$ But no "superspecial justifications" for reversing any of these decisions can be imagined at this point.

It also seems unlikely that Scalia's absence will alter the fundamental pro-owner orientation of the Roberts Court. The Court's veneration of property rights is reflected in the unanimous decision of McBurney v. Young, which emphasized that "the right to 'take, hold and dispose of property ...' has long been seen as one of the privileges of citizenship." 332 Consider, for example, the scope of the Takings Clause-perhaps the most controversial issue in modern constitutional property jurisprudence. The Roberts Court decided five cases on this subject before Scalia's death: Wilkie, Stop the Beach Renourishment, Koontz, Horne, and Arkansas Game \& Fish Commission. ${ }^{33}$ Scalia agreed with the outcome of all five decisions, but this only affected the result in Koontz. ${ }^{334}$ In the other four cases, majorities of seven or eight Justices agreed on the result-so Scalia's vote made no difference in the outcome. ${ }^{335}$ As this example suggests, owners will generally continue to win in the Roberts Court in civil property-related disputes.

Beyond this point, predicting the future trajectory of the Court's property jurisprudence is more difficult. Inevitable changes in the composition of the Court, as Scalia and perhaps others are replaced, will obviously affect its direction. But it appears that the four trends analyzed above will continue to shape the Court's property jurisprudence for some time to come, if perhaps with less force.

First, the propertization of the Constitution is likely to continue in Scalia's absence, if at a more gradual pace. It is important to remember that the strong pro-owner orientation of the Roberts Court shows no signs of abating. Chief Justice Roberts, Justice Kennedy, and Justice Alito, in particular, have emerged as leaders in the Court's modern property jurisprudence. Their future opinions will undoubtedly be

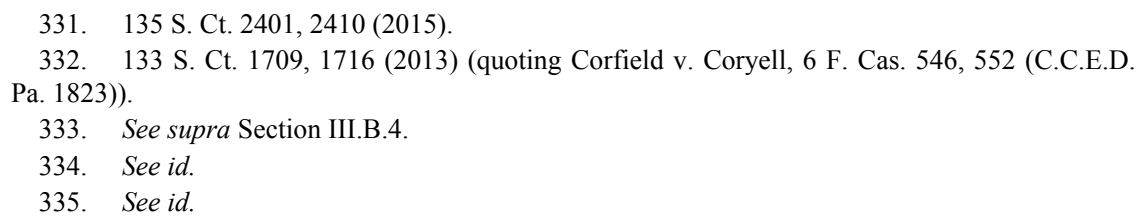


affected by Scalia's views, but will also certainly diverge from them in meaningful ways. The most important difference may be that Scalia forcefully advocated for groundbreaking expansions of property rights-as reflected in his Second and Fourth Amendment decisions and his ambitious dicta in Stop the Beach Renourishment-rather than incremental advances. Based on their past opinions, Roberts, Kennedy, and Alito, by contrast, will probably focus on more gradual extensions, and there is every reason to believe that other Justices will concur in this approach.

The parameters of the Court's sweeping Second and Fourth Amendment decisions will undoubtedly be the subject of extensive litigation, requiring it to refine these holdings. Because Justice Scalia was the most passionate supporter of these rulings, his absence from the Court will affect the outcome. It seems likely that the scope of Heller and McDonald will be narrowly confined to their facts-essentially allowing possession of certain weapons in the home-rather than expanded more broadly as Scalia presumably desired. ${ }^{336}$ And the JonesJardines definition of "constitutionally protected areas" will probably need clarification as a plethora of new cases will test its outer limits.

The Court's future Takings Clause jurisprudence is more problematic. Based on its first decade, it is reasonable to believe that the Roberts Court will continue to expand its scope-but without bold leaps. In particular, Stop the Beach Renourishment is a virtual invitation for property owners to claim that a judicial taking has occurred, under either the Takings Clause or the Due Process Clause. The vague distinction in Koontz between a monetary exaction and a tax will require clarification. Future cases in both areas will give the Court the opportunity to redefine the borders of these doctrines.

Second, it is likely that future decisions of the Roberts Court will be affected by its unusually strong pro-home orientation, which is shared by all the current Justices. Accordingly, it seems probable that the Court will continue to enlarge legal protection for the home in constitutional doctrine. For example, the Court might determine that a higher degree of "public use" is required before government may condemn a home or even revitalize the dormant Third Amendment by extending it to new

336. For example, in Friedman v. City of Highland Park, 136 S. Ct. 447 (2015), the Court refused to review the Circuit Court's ruling which interpreted Heller as applying only to possession of weapons within the home. Justice Scalia joined Justice Thomas' dissent from the denial of certiorari, which maintained that Heller also extended to possession of weapons outside of the home. Id. at 447-50 (Thomas, J., dissenting). 
situations. It is also conceivable that the Court could employ the proverbial "thin end of the wedge" approach, gradually widening proowner doctrines developed in home-protective decisions to encompass other forms of property, thereby broadening protection for property rights in general. ${ }^{33}$

Third, the Roberts Court may continue to weave professed fear of government misconduct into the rationales for its future property decisions, though this is less certain after Scalia's death. All the current Justices have either written or joined multiple opinions that express such distrust. ${ }^{338}$ To some extent, this development mirrors public sentiment. For example, during the Roberts Court era, the percentage of Americans who trust the federal government has significantly declined. ${ }^{339}$ In this atmosphere, it is unsurprising that the Stop the Beach Renourishment plurality would proclaim that the federal judiciary was "the branch of government whose procedures are, by far, the most protective of individual rights." ${ }^{340}$ But the Court's apparent reliance on distrust of other branches of government as a substantive rationale for its property decisions is troubling.

Fourth, the Roberts Court will inevitably need to confront the definition of "property" in future cases. The trend toward equating real property and personal property seems likely to continue, as evidenced by Horne-where six current Justices joined Chief Justice Roberts' opinion that no distinction was appropriate. ${ }^{341}$ Similarly, five current Justices appear to concur that a "right" may be "property" even if it has no ascertainable market value; it remains to be seen, however, whether they will adhere to this position when the issue is central to the outcome. Lastly, the tension between the static property and dynamic property theories is likely to remain unresolved for some time. Although Justice Scalia's absence will weaken support for the static theory, Chief Justice Roberts and Justices Alito and Thomas will undoubtedly continue to

337. Cf. Koontz v. St. Johns River Water Mgmt. Dist., 133 S. Ct. 2586, 2595 (2013) (extending the Nollan-Dolan standard from real property exactions to monetary payments, in part, because otherwise the government could "evade" that standard).

338. See supra Section III.D.

339. In September, 2005, 31\% of Americans reported that they would "trust the government in Washington to do what is right" either "just about always" or "most of the time," and by October, 2015, only $19 \%$ of Americans answered the same way. Beyond Distrust: How Americans View Their Government, PEW RES. CTR. 149-50 (Nov. 23, 2015), http://www.peoplepress.org/files/2015/11/11-23-2015-Governance-release.pdf.

340. Stop the Beach Renourishment, Inc. v. Fla. Dep't of Envtl. Prot., 560 U.S. 702, 720 (2010).

341. See Horne v. Dep’t of Agric., 135 S. Ct. 2419, 2423 (2015). 
press the Court to adopt it in the future.

\section{APPENDIX}

This study examined all Supreme Court decisions that met four criteria: (1) the underlying case involved a property-related dispute; ${ }^{342}$ (2) the case was argued before the Court during the tenure of Chief Justice Roberts; ${ }^{343}$ (3) the case was decided before Justice Scalia's death; ${ }^{344}$ and (4) one party to the case was a property owner ${ }^{345}$ as a petitioner or respondent and the opposing party was a government entity. ${ }^{346}$

\section{A. Civil Property-Related DeCisions By the RoBerts COURT}

Gonzales v. O Centro Espirita Beneficente Uniao do Vegetal, 546 U.S. 418 (2006): legality of possession and use of hallucinogenic tea under Religious Freedom Restoration Act; owner wins.

Jones v. Flowers, 547 U.S. 220 (2006): adequacy of notice of tax sale of home under Due Process Clause; owner wins.

Ark. Dep't of Health \& Human Servs. v. Ahlborn, 547 U.S. 268 (2006): validity of lien imposed by state on settlement fund under federal Medicaid statutes; owner wins.

Rapanos v. United States, 547 U.S. 715 (2006): validity of regulations defining wetlands under Clean Water Act which restrict owners from building; owners win.

342. This study takes a broad view of what constitutes a "property-related dispute," including disputes that go well beyond core property doctrines, as the case lists below demonstrate.

343. The first day on which the Court heard oral argument under Chief Justice Roberts was October 3, 2005, the first day of the 2005 term.

344. Justice Scalia died on February 13, 2016. None of the decisions from the Court's 2015 term that were issued before his death qualify for inclusion in this study.

345. The definition of "owner" includes (a) persons holding nonfreehold estates and (b) persons or entities who are acting as a surrogate for an owner by asserting a pro-property rights position, such as a trade association acting on behalf of members who own property.

346. This category includes suits against officials employed by government entities. It should be noted that under this approach, cases involving intellectual property, bankruptcy, Native American rights, and certain other cases which might be viewed as involving "property-related disputes" are omitted from the study because they do not involve a government entity as a party. Tax cases are similarly omitted due to their tenuous connection to property rights. 
Massachusetts v. EPA, 549 U.S. 497 (2007): authority of Environmental Protection Agency to regulate greenhouse gases to mitigate coastal flooding; owners (state and private parties representing owner side) win.

Envtl. Def. v. Duke Energy Corp., 549 U.S. 561 (2007): validity of regulations concerning replacement of electric generators under Clean Air Act; owner loses.

United Haulers Ass'n, Inc. v. Oneida-Herkimer Solid Waste Mgmt. Auth., 550 U.S. 330 (2007): validity of ordinances concerning solid waste under Interstate Commerce Clause; owner (trade group representing owners) loses.

United States v. Atl. Research Corp., 551 U.S. 128 (2007): right of owner of industrial facility to sue federal government for partial reimbursement of CERCLA cleanup costs; owner wins.

Wilkie v. Robbins, 551 U.S. 537 (2007): liability of government employees for allegedly trying to obtain easement from landowner by abusive means; owner loses.

District of Columbia v. Heller, 554 U.S. 570 (2008): validity of District of Columbia ordinances which effectively prohibit possession of a handgun in the home under the Second Amendment; owner wins.

Burlington N. \& Santa Fe Ry. Co. v. United States, 556 U.S. 599 (2009): liability of landowners to government for CERCLA cleanup costs; owners win.

Stop the Beach Renourishment, Inc. v. Fla. Dep't of Envtl. Prot., 560 U.S. 702 (2010): legality of judicial decision which allegedly takes property rights from coastal landowners under Takings Clause; owner group loses.

McDonald v. City of Chicago, 561 U.S. 742 (2010): validity of city ordinances that effectively prohibit possession of a handgun in the home under the Second Amendment; owners win. 
Am. Elec. Power Co., Inc. v. Connecticut, 564 U.S. 410 (2011): liability of power plant owners for greenhouse gas emissions under nuisance law; owners win.

Sorrell v. IMS Health, Inc., 564 U.S. 552 (2011): validity of law that restricts sale and use of pharmacy records; owner side wins.

Brown v. Entm't Merchs. Ass'n, 564 U.S. 786 (2011): validity of statute under First Amendment which restricts sales and other transfers of certain video games to minors; owners win.

Nat'l Meat Ass'n v. Harris, 132 S. Ct. 965 (2012): validity of statute that bans slaughter of animals; trade group representing owners wins.

Sackett v. EPA, 132 S. Ct. 1367 (2012): ability of landowners to challenge enforcement decision under Clean Water Act; owners win.

Match-E-Be-Nash-She-Wish Band of Pottawatomi Indians $v$. Patchak, 132 S. Ct. 2199 (2012): ability of neighboring landowner to challenge government decision to allow tribe to take land into trust; owner wins.

Ark. Game \& Fish Comm'n v. United States, 133 S. Ct. 511 (2012): liability of federal government under Takings Clause for downstream flooding; owner side wins (state acting in capacity of private owner).

Lozman v. City of Riviera Beach, 133 S. Ct. 735 (2013): validity of maritime lien imposed on floating home; owner wins.

Wos v. E.M.A. ex rel. Johnson, 133 S. Ct. 1391 (2013): validity of lien imposed by state on settlement fund under federal Medicaid statutes; owner wins.

Horne v. Dep't of Agric., 133 S. Ct. 2053 (2013): ability of owners to challenge decision of federal agency to seize raisins; owners win.

Koontz v. St. Johns River Water Mgmt. Dist., 133 S. Ct. 2586 (2013): liability of state agency under Takings Clause for imposing development mitigation fee; owners win. 
Marvin M. Brandt Revocable Tr. v. United States, 134 S. Ct. 1257 (2014): entitlement of government to easement on real property; owner wins.

T-Mobile S., LLC v. City of Roswell, 135 S. Ct. 808 (2015): legality of city's decision to refuse permit for construction of cell tower; owner wins.

Horne v. Dep't of Agric., 135 S. Ct. 2419 (2015): liability of government under Takings Clause for seizure of raisins; owners win.

City of Los Angeles v. Patel, 135 S. Ct. 2443 (2015): legality of ordinance under Fourth Amendment which allows police to search hotel records; owner side wins (represented by trade group).

Tex. Dep't of Hous. \& Cmty. Affairs v. Inclusive Cmtys. Project, Inc., 135 S. Ct. 2507 (2015): ability of property owners to sue under the Fair Housing Act on a disparate-impact theory; owner side wins.

\section{B. CRIMINAl Property-Related DeCISIONS By the RoBERTS COURT}

Will v. Hallock, 546 U.S. 345 (2006): liability of government agents under Bivens for damage to computer equipment taken from owners; owners lose.

United States v. Grubbs, 547 U.S. 90 (2006): Fourth Amendment decision; owner loses.

Georgia v. Randolph, 547 U.S. 103 (2006): Fourth Amendment decision; owner wins.

Brigham City v. Stuart, 547 U.S. 398 (2006): Fourth Amendment decision; owner loses.

Hudson v. Michigan, 547 U.S. 586 (2006): Fourth Amendment decision; owner loses.

Beard v. Banks, 548 U.S. 521 (2006): right of inmate under First Amendment to have access to newspapers, magazines, and photos; owner loses. 
Los Angeles County v. Rettele, 550 U.S. 609 (2007): Fourth Amendment decision; owner loses.

Watson v. United States, 552 U.S. 74 (2007): interpretation of criminal statute concerning "use" of a firearm; owner wins.

Ali v. Fed. Bureau of Prisons, 552 U.S. 214 (2008): liability of prison officials for mishandling inmate's belongings; owner loses.

Pearson v. Callahan, 555 U.S. 223 (2009): Fourth Amendment decision; owner loses.

Arizona v. Johnson, 555 U.S. 323 (2009): Fourth Amendment decision; owner loses.

Arizona v. Gant, 556 U.S. 332 (2009): Fourth Amendment decision; owner wins.

Michigan v. Fisher, 558 U.S. 45 (2009): Fourth Amendment decision; owner loses.

United States v. Stevens, 559 U.S. 460 (2010): right of defendant under First Amendment to possess photos depicting animal cruelty; owner wins.

Kentucky v. King, 563 U.S. 452 (2011): Fourth Amendment decision; owner loses.

Davis v. United States, 564 U.S. 229 (2011): Fourth Amendment decision; owner loses.

United States v. Jones, 132 S. Ct. 945 (2012): Fourth Amendment decision; owners win.

Ryburn v. Huff, 132 S. Ct. 987 (2012): Fourth Amendment decision; owners lose.

Messerschmidt v. Millender, 132 S. Ct. 1235 (2012): Fourth Amendment decision; owner loses. 
S. Union Co. v. United States, 132 S. Ct. 2344 (2012): liability of defendant for storing hazardous waste on its land; owner wins.

United States v. Alvarez, 132 S. Ct. 2537 (2012): legality of statute under First Amendment that criminalizes wearing unearned medals; owner wins.

Florida v. Harris, 133 S. Ct. 1050 (2013): Fourth Amendment decision; owner loses.

Florida v. Jardines, 133 S. Ct. 1409 (2013): Fourth Amendment decision; owner wins.

Stanton v. Sims, 134 S. Ct. 3 (2013): Fourth Amendment decision; owner loses.

Kaley v. United States, 134 S. Ct. 1090 (2014): legality under Sixth Amendment of protective order freezing assets of criminal defendants; owners lose.

Fernandez v. California, 134 S. Ct. 1126 (2014): Fourth Amendment decision; owner loses.

Riley v. California, 134 S. Ct. 2473 (2014): Fourth Amendment decision; owners win.

Carroll v. Carman, 135 S. Ct. 348 (2014): Fourth Amendment decision; owners lose.

Heien v. North Carolina, 135 S. Ct. 530 (2014): Fourth Amendment decision; owner loses.

Yates v. United States, 135 S. Ct. 1074 (2015): interpretation of Sarbanes-Oxley Act regarding whether a fish is a "tangible object"; owner wins.

Rodriguez v. United States, 135 S. Ct. 1609 (2015): Fourth Amendment decision; owner wins.

Henderson v. United States, 135 S. Ct. 1780 (2015): interpretation of statute criminalizing possession of a firearm by a felon; owner wins. 